\author{
Anar Rzayev, \\ Ph.D, Associate Professor, Azerbaijan State University of Economics, Republic of Azerbaijan \\ ORCID ID, 0000-0001-6767-4796 \\ email: anar.rzayev@unec.edu.az \\ Anastasiia Samoilikova, \\ Sumy State University, Ukraine \\ (iD) ORCID ID, 0000-0001-8639-5282 \\ email: av.samoilikova@finance.sumdu.edu.ua
}

Correspondence author: anar.rzayev@unec.edu.az

\title{
INNOVATION FINANCING STRUCTURE AS A FACTOR OF ECONOMIC GROWTH: CROSS COUNTRY ANALYSIS
}

Abstract. The article focuses on the level and dynamics of innovation financing in Azerbaijan and Ukraine compared to the world level and the places of Azerbaijan and Ukraine in the Global Innovation Index and trends in their positioning in the dynamics. The analysis reveals negative dynamics in both countries in this sphere. The innovation financing structure's role as a factor of economic growth and international reproductive relations development is substantiated. The dependence of the country's economic growth level (GDP growth per capita) on the value of expenditures on innovation financed by various sectors of the economy (government, the private nonprofit sector, foreign investors and the higher education sector) is studied. The study consists of data for 12 European countries for 2007-2017 (limited calculations in 2017 due to the availability of information on open portals of the World Bank, the EU Statistical Office). At the first stage, the distribution of the relevant indicators was evaluated using the Shapiro-Wilk test. Based on these results the method of calculating the correlation coefficient is chosen: Pearson for indices that are subject to the ordinary distribution law or Spearman - for indices that are not subject to the ordinary distribution law. A correlation analysis regarding the strength and nature of the relationship between relevant indices and the dynamics of GDP per capita in these countries is performed to identify the duration of time lags, after which this relationship is the most statistically significant. In the second stage, there are three types of regression models for estimating panel data to identify the impact on the economic growth dynamics of innovations financed by different economic sectors: 1) with fixed effects (based on the least-squares method); 2) with random effects (based on the general least squares method (GLS); 3) dynamic model for estimation of Arellano-Bond panel data, which considers time lags (based on the general method of moments (GMM)). In the third stage, using Wald's tests, Breusch-Pagan and Hausman, the adequate model specification is chosen. When choosing a dynamic model of Arellano-Bond, the Sargan test is performed to validate the parameters. The control variables in all three types of models consider net inflows and outflows of foreign investment, inflation (GDP deflator) and labour force participation rate (\% of total population ages 15-64). The second and third stages of the study obtained the results as follows. It is empirically confirmed that a $1 \%$ increase in the share of government sector-funded $R \& D$ expenditures leads to a decrease in annual GDP growth per capita by an average of $0.15 \%$ (excluding time), business sector - to the increase by $0.13 \%$ with a time lag of 2 years, thanks to foreign sources - to the increase by $0.1 \%$ (without time lag); higher education sector - to the decrease by $0.78 \%$ (without time lag). It is substantiated that the state should reduce the share of direct investment in innovation. At the same time, it should focus on effective legislation, motivating the business sector and foreign investors to increase investment in research and development to stimulate economic growth in Azerbaijan and Ukraine and the development of international reproductive relations.

Keywords: business sector, correlation analysis, dynamic model, economic growth, financial regulations, financing structure, foreign sources, GERD, government sector, influence formalization, innovation, regression model, R\&D.

Cite as: Rzayev, A., \& Samoilikova, A. (2020). Innovation Financing Structure as a Factor of Economic Growth: Cross Country Analysis. Marketing and Management of Innovations, 3, 133-156. http://doi.org/10.21272/mmi.2020.3-10 
Introduction. There are growing competition in domestic and global markets, uncertainty in the world economy while increasing requirements for its adaptability and digitalization. Consequently, innovation is the driving force of economic growth and development of international reproductive relations. The analysis reveals that in Azerbaijan and Ukraine, the dynamics of innovation development had been declining in recent years. The World Bank data showed that world innovation funding increased by $15.37 \%$ (from $1.97 \%$ of GDP in 1997 to $2.27 \%$ of GDP in 2018). It declined from $0.37 \%$ of GDP in 1997 to $0.18 \%$ in 2018 in Azerbaijan and from $1.19 \%$ of GDP in 1997 to $0.47 \%$ in 2018 in Ukraine. According to the Global Innovation Index 2019, Azerbaijan gained 84th place out of 129 (with a decrease of 2 positions compared to 2018), Ukraine - 47th place out of 129 (with a decline of four positions compared to 2018). In the report, Azerbaijan place is in the category of «in line with expectations for the level of development» (uppermiddle-income country). In turn, Ukraine is in the category of «above expectations for the level of development» (lower-middle-income country) and the countries rank N14 in NAWA region and N32 in EUR region respectively both countries have much larger potential in this sphere.

One of the reasons for underutilization of potential in the innovation development in Azerbaijan and Ukraine lays in the financial regulation and tools for implementing this area. Nowadays, financial regulations in general and the structure of innovation financing, in particular, is a critical component of innovation development, given the limited financial resources, the presence of strengths and weaknesses of alternative funding sources, the specific innovation and impact on economic growth and international reproductive relations.

Despite significant scientific achievements in this area, the impact of funding for innovation from the government sector, business sector, foreign and other sources on the dynamics of GDP per capita in modern economics is practically not covered and requires the empirical justification.

The paper aim is to study the innovation funding structure as a factor of economic growth and to formalize the impact of its components on the dynamics of GDP per capita.

Literature Review. A number of scientists has studied strong impact of investment on economic (Kwilinski, 2018; Czyżewski et al., 2019; Kwilinski \& Kuzior, 2020), social (Matijová et al., 2019; Kuznyetsova et al., 2018;), ecological (Dźwigoł \& Wolniak, 2018; Bertaccini \& Biagi, 2018), technological (Miśkiewicz \& Wolniak, 2020; Saługa et al., 2020) and financial development (Vovchak et al., 2018; Baranovskyi \& Khutorna, 2018; Kuznyetsova et al., 2019). Ketkar and Ratha (2009) focused their research on innovations in international finance that allow developing countries to engage in global capital markets, reducing their vulnerability to growth and fluctuations in capital flows. The authors draw attention to innovative mechanisms, innovative financing and restrictions on their use. Kotenko et al. (2015) studied the possibilities to finance innovations, in particular start-up companies and small businesses under the crowdfunding scheme, in the framework of attracting financial resources.

Mazzucato and Semieniuk (2017) highlighted new issues in public funding of innovation in three key areas: the availability of funding from public sources throughout the innovation chain; the concept of the mission-oriented regulation that has created new technological and industrial landscapes; the entrepreneurial role and the role of the leading investor of state entities that are willing and able to take extraordinary risks, regardless of the business cycle.

Grossman and Helpman (1991) studied innovation and growth in the global economy. Rosenberg (2006) considers technological innovation as the main force of economic growth, focuses on the features of innovation in the highly industrial economies of the OECD region, studies the impact of innovation on the tourism business model.

Broughel and Thierer (2019) similarly identify technological innovation as the main driver of economic growth and human progress and generalize approaches to assessing the impact of technological innovation on economic growth, living standards and human well-being. The authors also emphasize the 
role that government regulations can play in the development of innovation, growth and continuous improvement of the citizens' quality of life.

Nelson (2005) argues that the standard neoclassical theory of economic growth is inadequate to explain the economic growth phenomenon. He presents an alternative theory, which emphasizes that economic growth caused by the technological progress, considers this process as involving the coevolution of technology, institutions and industry structure.

As a result of the formation of a multiple regression model, Sokolov-Mladenovic et al. (2016) concluded that an increase in research and development spending as a percentage of GDP by $1 \%$ would increase the growth rate of real GDP by $2.2 \%$. The researchers paid special attention to the negative impact of the birth rate in the EU-28 on economic growth.

Pessoa (2007) traced the link between R\&D spending and economic growth, emphasizing that increasing R\&D spending is not a guaranteed way to improve economic growth, especially in countries below the technological frontier. Still, there are other ways in which technology affects growth, other than those based on formal research and development indicators.

Balashova (2015) examined the impact of such instruments as funding for research conducted in the government sector (in government research organizations and higher education institutions), funding for research conducted in the business sector (through government procurement, grants, etc.), tax subsidies and benefits provided to businesses for research and development - on the amount of funding by the business sector of internal research and development in OECD countries in the period from 1981 to 2012.

Methodology and research methods. The methods of correlation and regression analysis using the STATA software package for the sample from 12 European countries for 2007-2017 (limited calculations in 2017 due to the availability of information on open information portals of the World Bank, EU Statistical Office) were applied to confirm the hypothesis on the impact of the innovative financing structure on economic growth.

The nature of the distribution of the studied indicator was assessed using the Shapiro-Wilk test (Shapiro and Wilk, 1965). Based on those results the calculating method of the correlation coefficient was chosen: Pearson - for indicators subject to the law of normal distribution (Pearson, 1896), or Spearman for indicators do not obey the law of normal distribution (Spearman, 1904). A correlation analysis allowed establishing The strength and nature of the relationship between the indices of innovation funding structure and the dynamics of GDP per capita. It revealed the duration of time lags, after which this relationship is the most statistically significant.

There are three types of regression models to estimate the panel data to identify the impact on the economic growth dynamics of innovations funded by different economic sectors (Baltagi, 2013): 1) with fixed effects (based on the least-squares method) (Allison, 2009; Arellano, 1987); 2) with random effects (based on the general least squares method (GLS) (Schunck, 2013); 3) a dynamic model for estimating Arellano-Bond panel data, which considers time lags (based on the general method of moments (GMM)) (Arellano \& Bond, 1991). Wald, Breusch-Pagan, and Hausman tests selected the adequate model specification (Gourieroux and Monfort, 1995; Hausman, 1978). In the case of a dynamic Arellano-Bond model, the Sargan test for parameter validity was performed (Arellano and Bond, 1991).

Results. The study (Samoilikova, 2020) observed the empirical substantiation and formalization of the impact made by the financial regulations indices for innovation development on the overall level of innovation development in different European countries. One of the essential areas of financial regulations is to study the impact made by the structure of financing innovation as a factor in economic growth. One should note that innovative development involves a significant transfer of resources between economic sectors, organizations and countries. 
Gross expenditure on R\&D (GERD) (Table 1) includes the capital and current expenditures in four main sectors: the government, business, private non-profit and higher education sectors, covering fundamental and applied research and experimental development.

Table 1. Gross expenditure on R\&D (\% from GDP)

\begin{tabular}{|l|c|c|c|c|c|c|c|c|c|c|c|}
\hline Country & $\mathbf{2 0 0 7}$ & $\mathbf{2 0 0 8}$ & $\mathbf{2 0 0 9}$ & $\mathbf{2 0 1 0}$ & $\mathbf{2 0 1 1}$ & $\mathbf{2 0 1 2}$ & $\mathbf{2 0 1 3}$ & $\mathbf{2 0 1 4}$ & $\mathbf{2 0 1 5}$ & $\mathbf{2 0 1 6}$ & $\mathbf{2 0 1 7}$ \\
\hline Bulgaria & 0,43 & 0,45 & 0,49 & 0,56 & 0,53 & 0,60 & 0,64 & 0,79 & 0,96 & 0,78 & 0,75 \\
\hline Estonia & $\mathbf{1 , 0 7}$ & $\mathbf{1 , 2 6}$ & $\mathbf{1 , 4 0}$ & $\mathbf{1 , 5 8}$ & $\mathbf{2 , 3 1}$ & $\mathbf{2 , 1 2}$ & $\mathbf{1 , 7 2}$ & $\mathbf{1 , 4 3}$ & 1,47 & $\mathbf{1 , 2 5}$ & 1,29 \\
\hline Latvia & 0,55 & 0,58 & 0,45 & 0,61 & 0,70 & 0,66 & 0,61 & 0,69 & 0,63 & 0,44 & 0,51 \\
\hline Lithuania & 0,80 & 0,79 & 0,83 & 0,78 & 0,90 & 0,89 & 0,95 & 1,03 & 1,04 & 0,84 & 0,89 \\
\hline Poland & 0,56 & 0,60 & 0,66 & 0,72 & 0,75 & 0,88 & 0,87 & 0,94 & 1,00 & 0,96 & 1,03 \\
\hline Russian Federation & 1,12 & 1,04 & 1,25 & 1,13 & 1,01 & 1,03 & 1,03 & 1,07 & 1,10 & 1,10 & 1,11 \\
\hline Romania & 0,51 & 0,55 & 0,44 & 0,46 & 0,50 & 0,48 & 0,39 & 0,38 & 0,49 & 0,48 & 0,50 \\
\hline Slovakia & 0,45 & 0,46 & 0,47 & 0,62 & 0,66 & 0,80 & 0,82 & 0,88 & 1,17 & 0,79 & 0,88 \\
\hline Slovenia & 1,42 & 1,63 & 1,82 & 2,06 & 2,42 & 2,57 & 2,58 & 2,37 & 2,20 & 2,01 & 1,86 \\
\hline Hungary & 0,96 & 0,98 & 1,13 & 1,14 & 1,19 & 1,26 & 1,39 & 1,35 & 1,36 & 1,20 & 1,35 \\
\hline Ukraine & 0,85 & 0,85 & 0,86 & 0,83 & 0,74 & 0,75 & 0,76 & 0,65 & 0,61 & 0,48 & 0,45 \\
\hline Czech Republic & 1,30 & 1,24 & 1,29 & 1,34 & 1,56 & 1,78 & 1,90 & 1,97 & 1,93 & 1,68 & 1,79 \\
\hline
\end{tabular}

Source: developed by the authors based on WorldBank Data, Research and development expenditure, 2007-2017.

Figure 1 demonstrates the dynamics of changes in GERD for the period from 2007 to 2017 in European countries.

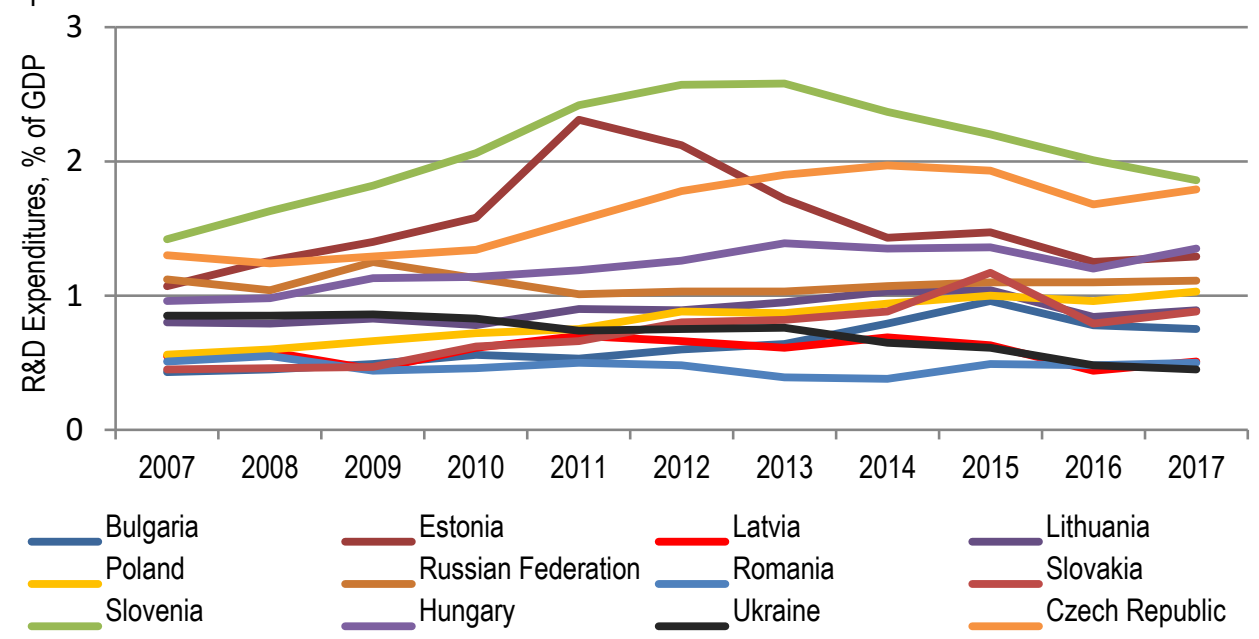

Figure 1. Dynamics of changes of R\&D expenditures in 2007-2017 (compiled by the author)

Source: developed by the authors based on WorldBank Data, Research and development expenditure, 2007-2017. 
The trend of changing the share of GERD in GDP differs significantly. It can be explained by individual economic development features as a whole and innovative development of different countries, in particular. Many EU countries have a gradual increase in this index since 2009 after the financial crisis (Estonia, Slovenia, Poland, the Czech Republic).

Figure 2 presents the dynamics of GERD in Ukraine and Azerbaijan in comparison with the EU. It clearly shows the declining trend and low level of funding for innovation in these countries, in contrast to the EU countries.

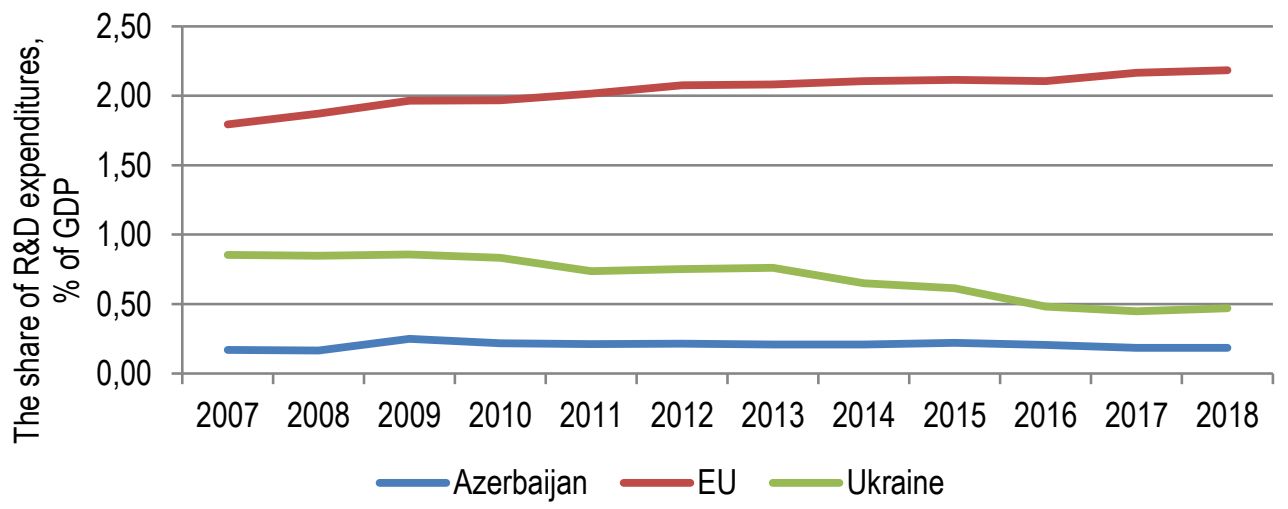

Figure 2. Dynamics of R\&D expenditures in Ukraine and Azerbaijan compared to the EU

Source: developed by the authors based on WorldBank Data, Research and development expenditure, 2007-2018.

The GERD has been analyzed by the main financing sources: the share of R\&D expenditures financed by the government sector (Table 2), the business sector (Table 3), the higher education sector (Table 4), the private non-profit sector (Table 5), at the expense of foreign sources (Table 6).

Table 2. Share of GERD financed by the government sector (\% of GERD)

\begin{tabular}{|l|c|c|c|c|c|c|c|c|c|}
\hline \multicolumn{1}{|c|}{ Country } & $\mathbf{2 0 0 7}$ & $\mathbf{2 0 0 9}$ & $\mathbf{2 0 1 1}$ & $\mathbf{2 0 1 2}$ & $\mathbf{2 0 1 3}$ & $\mathbf{2 0 1 4}$ & $\mathbf{2 0 1 5}$ & $\mathbf{2 0 1 6}$ & $\mathbf{2 0 1 7}$ \\
\hline Bulgaria & 56,7 & 60,5 & 38,8 & 31,5 & 31,6 & 26,4 & 20,3 & 21,8 & 24,3 \\
\hline Estonia & 45,6 & 48,8 & 32,8 & 38,3 & 47,2 & 49,5 & 46,4 & 37,6 & 40,2 \\
\hline Latvia & 49,9 & 44,7 & 22,5 & 23,9 & 23,9 & 25,6 & 32,7 & 47,7 & 43,6 \\
\hline Lithuania & 46,9 & 52,7 & 42,2 & 39,7 & 34,5 & 33,1 & 35,3 & 39,2 & 36,4 \\
\hline Poland & 58,6 & 60,4 & 55,8 & 51,3 & 47,2 & 45,2 & 41,8 & 38,9 & 38,3 \\
\hline $\begin{array}{l}\text { Russian } \\
\text { Federation }\end{array}$ & 62,6 & 66,5 & 67,1 & 67,8 & 67,6 & 69,2 & 69,5 & 66,2 & 67,0 \\
\hline Romania & 67,1 & 54,9 & 49,1 & 49,9 & 52,3 & 48,5 & 41,7 & 39,6 & 35,9 \\
\hline Slovakia & 53,9 & 50,6 & 49,8 & 41,6 & 38,9 & 41,4 & 31,9 & 41,0 & 35,5 \\
\hline Slovenia & 35,6 & 35,7 & 31,5 & 28,7 & 26,9 & 21,8 & 19,9 & 20,2 & 22,9 \\
\hline Hungary & 44,4 & 42,0 & 38,1 & 36,9 & 35,9 & 33,5 & 34,6 & 26,2 & 31,9 \\
\hline Ukraine & 52,2 & 49,8 & 43,8 & 50,3 & 47,7 & 45,8 & 40,1 & 39,3 & 44,2 \\
\hline Czech Republic & 44,7 & 47,8 & 41,7 & 36,8 & 34,7 & 32,9 & 32,2 & 35,6 & 34,6 \\
\hline
\end{tabular}

Source: developed by the authors based on Eurostat Data, GERD by the source of funds, 2007-2017; State Statistics Service of Ukraine, Science, Technology and Innovation, 2007-2017. 
Among these countries, the largest share of $R \& D$ expenditures financed by the government sector occurs in the Russian Federation, Latvia, Ukraine and Estonia. Instead, the lowest expenditures are in Slovenia and Bulgaria. It is worth noting that Slovenia has the highest share of R\&D expenditures in GDP with minimum R\&D expenditures financed by the government sector. In Ukraine, the Russian Federation and Latvia, with significant government sector funding, the share of R\&D expenditures in GDP is relatively low. However, for example, in Estonia during the selected period, the share of R\&D expenditures in GDP is relatively high with significant amounts of funding from the government sector. The situation is similar in other countries. So, it does not allow to make unambiguous conclusions about the relationship of the studied indices based on the data from Tables and graphs.

Table 3 demonstrates the indices of GERD share financed by the business sector in the studied countries. The highest rates of GERD financed by the business sector in 2017 are typical for Slovenia, Hungary, Romania, while the lowest - In Latvia, the Russian Federation, and Ukraine. However, these positions are not stable in dynamics.

Table 3. Share of GERD financed by the business sector (\% GERD)

\begin{tabular}{|l|c|c|c|c|c|c|c|c|c|c|c|}
\hline \multicolumn{1}{|c|}{ Country } & $\mathbf{2 0 0 7}$ & $\mathbf{2 0 0 8}$ & $\mathbf{2 0 0 9}$ & $\mathbf{2 0 1 0}$ & $\mathbf{2 0 1 1}$ & $\mathbf{2 0 1 2}$ & $\mathbf{2 0 1 3}$ & $\mathbf{2 0 1 4}$ & $\mathbf{2 0 1 5}$ & $\mathbf{2 0 1 6}$ & $\mathbf{2 0 1 7}$ \\
\hline Bulgaria & 34,2 & 30,6 & 30,2 & 16,7 & 16,9 & 20,8 & 19,5 & 22,3 & 35,6 & 43,6 & 43,2 \\
\hline Estonia & 41,6 & 39,8 & 38,5 & 43,6 & 55 & 51,3 & 42,1 & 37,1 & 41 & 48,2 & 43,6 \\
\hline Latvia & 36,4 & 27,0 & 36,9 & 38,8 & 24,8 & 23,7 & 21,8 & 27,8 & 20,0 & 21,6 & 24,1 \\
\hline Lithuania & 32,8 & 29,3 & 30,8 & 32,4 & 28,2 & 26,5 & 27,5 & 32,7 & 28,5 & 39 & 35,4 \\
\hline Poland & 34,3 & 30,5 & 27,1 & 24,4 & 28,1 & 32,3 & 37,3 & 39,0 & 39,0 & 53,1 & 52,5 \\
\hline $\begin{array}{l}\text { Russian } \\
\text { Federation }\end{array}$ & 29,4 & 28,7 & 26,6 & 25,5 & 27,7 & 27,2 & 28,2 & 27,1 & 26,5 & 30,2 & 29,5 \\
\hline Romania & 26,9 & 23,3 & 34,8 & 32,3 & 37,4 & 34,4 & 31,0 & 32,9 & 37,3 & 49,4 & 54,4 \\
\hline Slovakia & 35,6 & 34,7 & 35,1 & 35,1 & 33,9 & 37,7 & 40,2 & 32,2 & 25,1 & 46,2 & 49,0 \\
\hline Slovenia & 58,3 & 62,8 & 58 & 58,4 & 61,2 & 62,2 & 63,8 & 68,4 & 69,2 & 69,2 & 63,1 \\
\hline Hungary & 43,9 & 48,3 & 46,4 & 47,4 & 47,5 & 46,9 & 46,8 & 48,3 & 49,7 & 56,4 & 52,7 \\
\hline Ukraine & 30,2 & 27,1 & 25,9 & 23,8 & 24,6 & 28,6 & 29,0 & 32,9 & 39,6 & 36,9 & 30,1 \\
\hline $\begin{array}{l}\text { Czech } \\
\text { Republic }\end{array}$ & 47,2 & 45,0 & 39,8 & 40,8 & 37,7 & 36,4 & 37,6 & 35,9 & 34,5 & 39,5 & 39,3 \\
\hline
\end{tabular}

Source: developed by the authors based on Eurostat Data, GERD by the source of funds, 2007-2017; State Statistics Service of Ukraine, Science, Technology and Innovation, 2007-2017.

Similarly, we consider the indices of GERD financed by the higher education sector, which is insignificant in size compared to the first two surveyed sectors (Table 4).

Table 4. Share of GERD financed by the higher education sector (\% of GERD)

\begin{tabular}{|l|c|c|c|c|c|c|c|c|c|c|c|}
\hline \multicolumn{1}{|c}{ Country } & $\mathbf{2 0 0 7}$ & $\mathbf{2 0 0 8}$ & $\mathbf{2 0 0 9}$ & $\mathbf{2 0 1 0}$ & $\mathbf{2 0 1 1}$ & $\mathbf{2 0 1 2}$ & $\mathbf{2 0 1 3}$ & $\mathbf{2 0 1 4}$ & $\mathbf{2 0 1 5}$ & $\mathbf{2 0 1 6}$ & $\mathbf{2 0 1 7}$ \\
\hline Bulgaria & 1,0 & 0,4 & 0,7 & 0,5 & 0,2 & 0,2 & 0,1 & 0,0 & 0,1 & 0,1 & 0,1 \\
\hline Estonia & 0,9 & 0,5 & 0,7 & 0,6 & 0,3 & 0,3 & 0,3 & 0,9 & 0,2 & 0,3 & 1,0 \\
\hline Latvia & 0,9 & 2,5 & 3,0 & 1,4 & 1,6 & 2,0 & 2,7 & 2,3 & 2,2 & 2,9 & 2,5 \\
\hline Lithuania & 0,2 & 0,3 & 3,2 & 1,5 & 1,0 & 0,5 & 0,1 & 0,2 & 1,5 & 2,4 & 3,7 \\
\hline Poland & 0,2 & 4,1 & 6,7 & 2,5 & 2,4 & 2,6 & 2,1 & 2,2 & 2,2 & 2,4 & 3,0 \\
\hline $\begin{array}{l}\text { Russian } \\
\text { Federation }\end{array}$ & 0,6 & 0,5 & 0,4 & 0,5 & 0,8 & 0,8 & 1,0 & 1,1 & 1,2 & 0,8 & 0,9 \\
\hline Romania & 1,4 & 2,6 & 1,9 & 2,2 & 1,2 & 1,0 & 1,1 & 1,4 & 1,7 & 1,1 & 1,7 \\
\hline Slovakia & 0,2 & 0,3 & 0,6 & 0,4 & 1,8 & 1,7 & 2,7 & 2,2 & 3,3 & 1,9 & 1,6 \\
\hline Slovenia & 0,4 & 0,3 & 0,3 & 0,3 & 0,2 & 0,4 & 0,3 & 0,5 & 0,3 & 0,4 & 0,5 \\
\hline Hungary & - & - & - & - & - & - & - & - & - & - & - \\
\hline
\end{tabular}


Continued Table 4

\begin{tabular}{|l|c|c|c|c|c|c|c|c|c|c|c|}
\hline Ukraine & 0,2 & 0,3 & 0,3 & 0,2 & 0,2 & 0,2 & 0,2 & 0,1 & 0,1 & 0,2 & 0,2 \\
\hline $\begin{array}{l}\text { Czech } \\
\text { Republic }\end{array}$ & 0,8 & 1,3 & 1,2 & 0,9 & 0,9 & 0,9 & 0,5 & 0,6 & 0,7 & 0,8 & 1,0 \\
\hline
\end{tabular}

Source: developed by the authors based on Eurostat Data, GERD by the source of funds, 2007-2017; State Statistics Service of Ukraine, Science, Technology and Innovation, 2007-2017.

It should be noted that there are no data on this source of R\&D expenditure for Hungary. Thus, it is impossible to compare it with other countries by this index. On average, during 2007-2017, the highest rate was in Poland, Latvia and Romania, the lowest in Ukraine, Bulgaria, Slovenia and Estonia.

Similarly, to the higher education sector as a source of funding, the non-profit sector finances a small share of GERD in the studied countries (Table 5).

Table 5. Share of GERD financed by the private non-profit sector (\% of GERD)

\begin{tabular}{|l|c|c|c|c|c|c|c|c|c|c|c|}
\hline \multicolumn{1}{|c|}{ Country } & $\mathbf{2 0 0 7}$ & $\mathbf{2 0 0 8}$ & $\mathbf{2 0 0 9}$ & $\mathbf{2 0 1 0}$ & $\mathbf{2 0 1 1}$ & $\mathbf{2 0 1 2}$ & $\mathbf{2 0 1 3}$ & $\mathbf{2 0 1 4}$ & $\mathbf{2 0 1 5}$ & $\mathbf{2 0 1 6}$ & $\mathbf{2 0 1 7}$ \\
\hline Bulgaria & 0,5 & 0,9 & 0,2 & 0,1 & 0,2 & 1,3 & 0,5 & 0,4 & 0,1 & 0,3 & 0,2 \\
\hline Estonia & 0,2 & 0,3 & 0,7 & 0,2 & 0,1 & 0,1 & 0,1 & 0,1 & 0,2 & 0,3 & 0,3 \\
\hline Latvia & 0,5 & 0,3 & 0,3 & 0,2 & 0,2 & 0,2 & 0,7 & 0,2 & 0,3 & 0,2 & 0,1 \\
\hline Lithuania & 0,1 & - & 0,1 & 0,1 & 1,2 & 1,4 & 1,0 & 0,2 & 0,2 & 0,2 & 0,3 \\
\hline Poland & 0,2 & 0,2 & 0,3 & 0,3 & 0,2 & 0,4 & 0,2 & 0,2 & 0,2 & 0,2 & 0,3 \\
\hline $\begin{array}{l}\text { Russian } \\
\text { Federation }\end{array}$ & 0,1 & 0,2 & 0,1 & 0,1 & 0,2 & 0,1 & 0,1 & 0,2 & 0,2 & 0,3 & 0,3 \\
\hline Romania & 0,0 & 0,0 & 0,1 & 0,0 & 0,2 & 0,2 & 0,0 & 0,1 & 0,1 & 0,1 & 0,0 \\
\hline Slovakia & 0,1 & 0,4 & 1,0 & 0,3 & 0,4 & 0,3 & 0,2 & 0,5 & 0,3 & 0,1 & 0,2 \\
\hline Slovenia & 0,0 & 0,0 & 0,0 & 0,1 & 0,0 & 0,1 & 0,0 & 0,0 & 0,0 & 0,0 & 0,4 \\
\hline Hungary & 0,6 & 0,6 & 0,7 & 0,9 & 1,0 & 0,9 & 0,8 & 0,7 & 0,7 & 0,7 & 0,5 \\
\hline Ukraine & 0,1 & 0,1 & 0,1 & 0,1 & 0,1 & 0,1 & 0,1 & 0,0 & 0,0 & 0,0 & 0,0 \\
\hline $\begin{array}{l}\text { Czech } \\
\text { Republic }\end{array}$ & 0,0 & 0,0 & 0,0 & 0,0 & 0,0 & 0,0 & 0,1 & 0,1 & 0,1 & 0,1 & 0,1 \\
\hline
\end{tabular}

Source: developed by the authors based on Eurostat Data, GERD by the source of funds, 2007-2017; State Statistics Service of Ukraine, Science, Technology and Innovation, 2007-2017.

In particular, in Ukraine since 2014, the private non-profit sector does not practically finance GERD. There was a similar situation in other countries (Slovenia, Czech Republic) during some periods. Lithuania, Hungary, Slovakia, and Romania have a relatively high level of R\&D expenditures financing from the private non-profit sector. Instead, low - in Ukraine, the Czech Republic, Slovenia, etc.

The last of GERD financing sources are funds from foreign sources (Table 6).

Table 6. Share of GERD financed by foreign sources (\% of GERD)

\begin{tabular}{|l|c|c|c|c|c|c|c|c|c|c|c|}
\hline \multicolumn{1}{|c|}{ Country } & $\mathbf{2 0 0 7}$ & $\mathbf{2 0 0 8}$ & $\mathbf{2 0 0 9}$ & $\mathbf{2 0 1 0}$ & $\mathbf{2 0 1 1}$ & $\mathbf{2 0 1 2}$ & $\mathbf{2 0 1 3}$ & $\mathbf{2 0 1 4}$ & $\mathbf{2 0 1 5}$ & $\mathbf{2 0 1 6}$ & $\mathbf{2 0 1 7}$ \\
\hline Bulgaria & 7,6 & 6,8 & 8,4 & 39,6 & 43,9 & 46,3 & 48,3 & 50,9 & 43,8 & 34,2 & 32,2 \\
\hline Estonia & 11,7 & 9,4 & 11,3 & 11,4 & 11,9 & 10,0 & 10,3 & 12,5 & 12,2 & 13,6 & 15,0 \\
\hline Latvia & 12,7 & 23,1 & 15,4 & 33,4 & 51,0 & 50,4 & 51,6 & 44,2 & 45,0 & 27,8 & 29,8 \\
\hline Lithuania & 19,6 & 15,5 & 13 & 19,9 & 28,4 & 33,2 & 37,1 & 33,8 & 34,3 & 19,2 & 24,4 \\
\hline Poland & 6,7 & 5,4 & 5,5 & 11,8 & 13,4 & 13,3 & 13,1 & 13,4 & 16,7 & 5,5 & 6,0 \\
\hline $\begin{array}{l}\text { Russian } \\
\text { Federation }\end{array}$ & 7,2 & 5,9 & 6,5 & 3,5 & 4,3 & 4,0 & 3,0 & 2,5 & 2,6 & 2,6 & 2,3 \\
\hline Romania & 4,5 & 4,0 & 8,3 & 11,1 & 12,1 & 14,4 & 15,5 & 17,0 & 19,2 & 9,9 & 7,9 \\
\hline Slovakia & 10,2 & 12,3 & 12,8 & 14,7 & 14,2 & 18,7 & 18,0 & 23,7 & 39,4 & 10,7 & 13,7 \\
\hline
\end{tabular}


Continued Table 6

\begin{tabular}{|l|c|c|c|c|c|c|c|c|c|c|c|}
\hline Slovenia & 5,8 & 5,6 & 6,0 & 6,0 & 7,0 & 8,6 & 8,9 & 9,3 & 10,6 & 10,2 & 13,1 \\
\hline Hungary & 11,1 & 9,3 & 10,9 & 12,4 & 13,5 & 15,4 & 16,6 & 17,5 & 15 & 16,6 & 14,9 \\
\hline Ukraine & 15,9 & 15,6 & 22,3 & 25,7 & 24,1 & 19,4 & 21,6 & 20,4 & 18,9 & 22,1 & 24,4 \\
\hline $\begin{array}{l}\text { Czech } \\
\text { Republic }\end{array}$ & 7,3 & 8,9 & 11,3 & 13,9 & 19,7 & 25,9 & 27,2 & 30,5 & 32,5 & 24,0 & 25,0 \\
\hline
\end{tabular}

Source: developed by the authors based on Eurostat Data, GERD by the source of funds, 2007-2017; State Statistics Service of Ukraine, Science, Technology and Innovation, 2007-2017.

In contrast to the share of financial support for innovation development from the higher education sector or the non-profit sector of the economy, GERD financing from foreign sources in many countries plays a significant role alongside funding from the government and business sectors. For example, in Latvia in 2011-2013, the share of GERD financing from foreign sources exceeded 50\%. Thus, the highest value of this index from 2015 to 2017 is observed in Bulgaria and Latvia, Ukraine and the Czech Republic, the lowest - in the Russian Federation, Poland, Romania.

Table 7 demonstrates the results of the investigation on the indices of the considered sources of GERD financing affect the country's economic growth, represented by the index of change in GDP per capita.

Table 7. Annual change of GDP per capita (\% to previous year)

\begin{tabular}{|l|c|c|c|c|c|c|c|c|c|c|c|}
\hline \multicolumn{1}{|c|}{ Country } & $\mathbf{2 0 0 7}$ & $\mathbf{2 0 0 8}$ & $\mathbf{2 0 0 9}$ & $\mathbf{2 0 1 0}$ & $\mathbf{2 0 1 1}$ & $\mathbf{2 0 1 2}$ & $\mathbf{2 0 1 3}$ & $\mathbf{2 0 1 4}$ & $\mathbf{2 0 1 5}$ & $\mathbf{2 0 1 6}$ & $\mathbf{2 0 1 7}$ \\
\hline Bulgaria & 8,14 & 6,77 & $-2,96$ & 1,99 & 2,57 & 0,61 & 1,06 & 2,42 & 4,13 & 4,67 & 4,57 \\
\hline Estonia & 8,07 & $-4,83$ & $-14,27$ & 2,94 & 7,77 & 3,48 & 1,71 & 3,26 & 1,78 & 2,60 & 5,62 \\
\hline Latvia & 10,91 & $-2,33$ & $-12,81$ & $-2,46$ & 8,24 & 5,43 & 3,43 & 2,88 & 4,11 & 2,71 & 4,71 \\
\hline Lithuania & 12,41 & 3,69 & $-13,86$ & 3,63 & 8,45 & 5,24 & 4,61 & 4,40 & 3,00 & 3,87 & 5,72 \\
\hline Poland & 7,09 & 4,24 & 2,75 & 3,90 & 4,96 & 1,61 & 1,45 & 3,40 & 3,91 & 3,11 & 4,92 \\
\hline $\begin{array}{l}\text { Russian } \\
\text { Federation }\end{array}$ & 8,69 & 5,25 & $-7,83$ & 4,45 & 4,22 & 3,53 & 1,58 & $-1,08$ & $-2,52$ & 0,15 & 1,52 \\
\hline Romania & 8,83 & 11,14 & $-4,73$ & $-3,33$ & 2,51 & 2,53 & 3,90 & 3,80 & 4,36 & 5,40 & 7,74 \\
\hline Slovakia & 10,80 & 5,48 & $-5,58$ & 5,62 & 2,73 & 1,72 & 0,56 & 2,65 & 4,72 & 1,99 & 2,88 \\
\hline Slovenia & 6,38 & 3,35 & $-8,38$ & 0,90 & 0,65 & $-2,84$ & $-1,16$ & 2,67 & 2,13 & 3,05 & 4,77 \\
\hline Hungary & 0,40 & 1,24 & $-6,55$ & 0,89 & 2,11 & $-0,96$ & 2,24 & 4,48 & 4,09 & 2,50 & 4,60 \\
\hline Ukraine & 8,24 & 2,86 & $-14,38$ & 4,25 & 5,85 & 0,49 & 0,20 & $-1,14$ & $-9,44$ & 2,85 & 2,92 \\
\hline $\begin{array}{l}\text { Czech } \\
\text { Republic }\end{array}$ & 4,99 & 1,83 & $-5,34$ & 1,98 & 1,57 & $-0,94$ & $-0,52$ & 2,61 & 5,10 & 2,25 & 4,08 \\
\hline
\end{tabular}

Source: developed by the authors based on WorldBank Data, GDP per capita growth, 2007-2017.

Confirmation or refutation of the hypothesis regarding the impact of GERD financed by various economic sectors on the change of GDP per capita is justified primarily by the calculation of the relevant correlation coefficients. Before that, it is necessary to check whether the indices of GERD share financed by the government sector (GS), the business sector (BS), the higher education sector (ES), the private non-profit sector (NS) and foreign sources (FS). The mentioned above subjects to testing the normal distribution using the Shapiro-Wilk test (Table 8) based on the data from Table 2-6. Calculations are performed in the STATA software package.

Accordingly, the Pearson correlation coefficient calculation defines the strength and nature of the relationship between the indices that obey the normal distribution law (Shapiro-Wilk test result> 0.05). Instead, the Spearman correlation coefficient calculation allowed identifying the relationship between indices that do not obey the normal distribution law (Shapiro-Wilk test result <0.05). Besides, the approximation of the results to the actual realities of the country's economic and innovative development 
determines the feasibility of identifying the correlation coefficients taking into account the time lags between the studied indices to increase their adequacy.

Table 8. The results of the Shapiro-Wilk test regarding the indices subordination for GERD financing structure to the normal distribution

\begin{tabular}{|c|c|c|c|c|c|c|c|c|c|}
\hline & $\mathbf{W}$ & $\mathbf{V}$ & $\mathbf{z}$ & Prob>z & & $\mathbf{W}$ & $\mathbf{V}$ & $\mathbf{z}$ & Prob>z \\
\hline \multicolumn{5}{|c|}{ Bulgaria } & \multicolumn{5}{|c|}{ Estonia } \\
\hline GS & 0,87962 & 1,949 & 1,265 & 0,10291 & GS & 0,91505 & 1,375 & 0,584 & 0,27952 \\
\hline BS & 0,90722 & 1,502 & 0,752 & 0,22598 & BS & 0,91280 & 1,412 & 0,634 & 0,26312 \\
\hline ES & 0,85958 & 2,274 & 1,582 & 0,05686 & ES & 0,01219 & 1,422 & 0,647 & 0,25884 \\
\hline NS & 0,83019 & 2,749 & 1,987 & $0,02348^{*}$ & NS & 0,78824 & 3,429 & 2,479 & 0,00659 \\
\hline FS & 0,81750 & 2,955 & 2,145 & $0,01599^{*}$ & FS & 0,96583 & 0,553 & 1,001 & 0,84162 \\
\hline \multicolumn{5}{|c|}{ Latvia } & \multicolumn{5}{|c|}{ Lithuania } \\
\hline GS & 0,83562 & 2,662 & 1,916 & $0,02767^{*}$ & GS & 0,92277 & 1,250 & 0,406 & 0,34243 \\
\hline BS & 0,85693 & 2,316 & 1,621 & 0,05253 & BS & 0,93704 & 1,019 & 0,034 & 0,48637 \\
\hline ES & 0,94693 & 0,859 & 0,266 & 0,60505 & ES & 0,87217 & 2,070 & 1,387 & 0,08265 \\
\hline NS & 0,84955 & 2,463 & 1,727 & $0,04210^{*}$ & NS & 0,76364 & 3,827 & 2,734 & $0,00313^{*}$ \\
\hline FS & 0,90798 & 1,490 & 0,736 & 0,23075 & FS & 0,91895 & 1,312 & 0,496 & 0,30998 \\
\hline \multicolumn{5}{|c|}{ Poland } & \multicolumn{5}{|c|}{ Russian Federation } \\
\hline GS & 0,88664 & 1,835 & 1,144 & 0,12621 & GS & 0,95954 & 0,655 & $-0,725$ & 0,76591 \\
\hline BS & 0,90051 & 1,611 & 0,887 & 0,18752 & BS & 0,97093 & 0,471 & $-1,258$ & 0,89577 \\
\hline ES & 0,82175 & 2,886 & 2,093 & $0,01819^{*}$ & ES & 0,97104 & 0,469 & $-1,264$ & 0,89686 \\
\hline NS & 0,86858 & 2,128 & 1,444 & 0,07434 & NS & 0,95474 & 0,733 & $-0,538$ & 0,70485 \\
\hline FS & 0,83791 & 2,624 & 1,886 & $0,02965^{*}$ & FS & 0,86526 & 2,182 & 1,496 & 0,06735 \\
\hline \multicolumn{5}{|c|}{ Romania } & & \multicolumn{4}{|c|}{ Slovakia } \\
\hline GS & 0,94330 & 0,918 & $\begin{array}{c}- \\
0,151 \\
\end{array}$ & 0,56007 & GS & 0,92460 & 1,221 & 0,361 & 0,35887 \\
\hline BS & 0,90270 & 1,575 & 0,844 & 0,19936 & BS & 0,92966 & 1,139 & 0,234 & 0,40742 \\
\hline ES & 0,92840 & 1,159 & 0,267 & 0,39489 & ES & 0,92796 & 1,166 & 0,278 & 0,39062 \\
\hline NS & 0,95474 & 0,733 & 0,538 & 0,70485 & NS & 0,82066 & 2,904 & 2,106 & $0,01759^{*}$ \\
\hline FS & 0,96870 & 0,507 & $\begin{array}{c}- \\
1,141\end{array}$ & 0,87314 & FS & 0,75066 & 4,037 & 2,860 & $0,00212^{*}$ \\
\hline \multicolumn{5}{|c|}{ Slovenia } & \multicolumn{5}{|c|}{ Hungary } \\
\hline GS & 0,89137 & 1,759 & 1,060 & 0,14463 & GS & 0,97485 & 0,407 & $-1,482$ & 0,93085 \\
\hline BS & 0,93704 & 1,019 & 0,034 & 0,48637 & BS & 0,87570 & 2,013 & 1,330 & 0,09171 \\
\hline ES & 0,93433 & 1,063 & 0,110 & 0,45632 & ES & - & - & - & - \\
\hline NS & 0,66503 & 5,424 & 3,587 & $0,00017^{*}$ & NS & 0,97850 & 0,348 & $-1,720$ & 0,95725 \\
\hline FS & 0,91374 & 1,397 & 0,613 & 0,26993 & FS & 0,94069 & 0,960 & $-0,072$ & 0,52865 \\
\hline \multicolumn{5}{|c|}{ Ukraine } & \multicolumn{5}{|c|}{ Czech Republic } \\
\hline GS & 0,94548 & 0,883 & $-0,219$ & 0,58686 & GS & 0,88652 & 1,837 & 1,147 & 0,12578 \\
\hline BS & 0,92967 & 1,139 & 0,234 & 0,40753 & BS & 0,91772 & 1,332 & 0,524 & 0.30007 \\
\hline ES & 0,99751 & 0,040 & $-4,510$ & 1,00000 & ES & 0,97757 & 0,363 & $-1,656$ & 0,95113 \\
\hline NS & 0,94674 & 0,862 & $-0,260$ & 0,60264 & NS & 0,99219 & 1,127 & $-3,128$ & 0,99912 \\
\hline FS & 0,95150 & 0,785 & $-0,421$ & 0,66319 & FS & 0,92193 & 1,264 & 0,426 & 0,33506 \\
\hline
\end{tabular}


Table 9 demonstrates the generalized results of the assessment of the relationship between the financial support of innovative development (according to GERD financing sources) and the change in GDP per capita.

Table 9. Assessment of the relationship between the financial support of innovative development (by GERD financing sources) and the annual change in GDP per capita (GDP)

\begin{tabular}{|c|c|c|c|c|c|c|c|c|c|c|}
\hline \multirow[b]{3}{*}{ Country } & \multicolumn{10}{|c|}{ Correlation between GDP and: } \\
\hline & \multicolumn{2}{|c|}{ GS } & \multicolumn{2}{|c|}{ BS } & \multirow{2}{*}{ 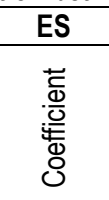 } & \multicolumn{3}{|c|}{ NS } & \multicolumn{2}{|c|}{ FS } \\
\hline & 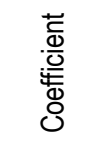 & 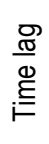 & 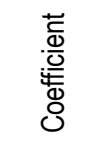 & 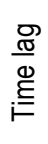 & & 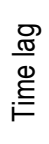 & $\begin{array}{l}+\frac{\bar{d}}{0} \\
\frac{0}{0} \\
0 \\
0\end{array}$ & 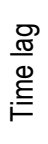 & 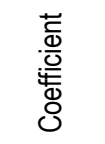 & $\frac{\text { D্ত }}{\stackrel{\Phi}{E}}$ \\
\hline Bulgaria & -0.7706 & 3 & 0.4598 & 0 & -0.8364 & 2 & -0.7714 & 0 & 0.9429 & 3 \\
\hline Estonia & -0.5480 & 0 & 0.4880 & 0 & -0.4553 & 2 & 0.8281 & 2 & 0.5460 & 2 \\
\hline Latvia & 0.6957 & 3 & -0.4707 & 0 & -0.5634 & 0 & -0.7775 & 1 & 0.5603 & 1 \\
\hline Lithuania & -0.5057 & 2 & 0.5336 & 3 & -0.5187 & 0 & -0.7537 & 3 & -0.4777 & 3 \\
\hline Poland & -0.5248 & 3 & 0.6710 & 3 & 0.4638 & 1 & 0.8918 & 5 & 0.8407 & 3 \\
\hline Russian Federation & -0.5606 & 3 & -0.6071 & 2 & -0.5614 & 3 & * & * & 0.6657 & 3 \\
\hline Romania & -0.9758 & 2 & 0.8467 & 2 & -0.6510 & 1 & 0.5150 & 2 & 0.9455 & 2 \\
\hline Slovakia & -0.6652 & 2 & -0.5410 & 0 & 0.4857 & 2 & -0.6983 & 2 & 0.6571 & 3 \\
\hline Slovenia & -0.8664 & 3 & 0.8442 & 3 & 0.4787 & 2 & -0.4456 & 1 & 0.7858 & 3 \\
\hline Hungary & -0.7635 & 3 & 0.7130 & 2 & - & - & 0.5336 & 3 & 0.8065 & 2 \\
\hline Ukraine & 0.8597 & 4 & 0.7967 & 4 & * & * & * & * & 0.5155 & 1 \\
\hline Czech Republic & -0.7791 & 3 & -0.7108 & 2 & -0.7141 & 1 & 0.6572 & 1 & 0.6970 & 2 \\
\hline
\end{tabular}

- no data; * the effect remains statistically insignificant on the acceptable calculation interval with a time lag from 0 to 5 years

Source: developed by the authors.

Table 10 summarizes the criteria to estimate correlation coefficients to define the strength and nature of the relationship between the studied indices.

Table 10. Generalized criteria for estimating correlation coefficients

\begin{tabular}{|c|c|c|c|}
\hline $\begin{array}{l}\text { Correlation } \\
\text { coefficient }\end{array}$ & $\begin{array}{l}\text { The strength of the } \\
\text { relationship }\end{array}$ & $\begin{array}{l}\text { Correlation } \\
\text { coefficient }\end{array}$ & $\begin{array}{c}\text { The character of the } \\
\text { relationship }\end{array}$ \\
\hline $0-0,3$ & Very weak & \multirow{2}{*}{$<0$} & \multirow{2}{*}{$\begin{array}{l}\text { Converse } \\
\text { (negative) }\end{array}$} \\
\hline $0,3-0,5$ & Weak & & \\
\hline $0,5-0,7$ & Average & \multirow{3}{*}{$>0$} & \multirow{3}{*}{$\begin{array}{c}\text { Direct } \\
\text { (positive) }\end{array}$} \\
\hline $0,7-0,9$ & High & & \\
\hline $0,9-1$ & Very high & & \\
\hline
\end{tabular}

Source: developed by the authors.

It is supposed that the impact is not statistically significant with a very weak and weak relationship between the indices. Significant influence occurs at a correlation coefficient of 0.7 , average - from 0.5 to 0.7 .

Thus, the correlation analysis of GERD impact financed by the government, business, private nonprofit sectors, foreign sources and the higher education sector on GDP per capita dynamics in these countries revealed the duration of time lags, due to which this impact becomes statistically significant: 
- the impact of the GERD share financed by government sector on GDP per capita: high - in Romania (with a lag of 2 years), in Bulgaria, Latvia, Slovenia, Hungary and the Czech Republic (with a lag of 3 years), in Ukraine (with time lag in 4 years); average - in Estonia (without time lag), in Lithuania and Slovakia (with a lag of 2 years), Poland, the Russian Federation (with a lag of 3 years). The character of the relationship for 10 countries in the study sample is inverse, for 2 countries - direct;

- the impact of GERD share financed by the business sector on GDP per capita: high - in Romania, Hungary and the Czech Republic (with a lag of 2 years), in Slovenia and Poland (with a lag of 3 years), in Ukraine 4 years); average - in Bulgaria, Estonia, Latvia and Slovakia (without time lag), in the Russian Federation (with a lag of 2 years), in Lithuania (with a lag of 3 years). The character of the relationship for 8 countries in the study sample is direct, for 4 countries - inverse;

- the impact of GERD share financed by the higher education sector on GDP per capita: high - in Romania and the Czech Republic (with a lag of 1 year), in Bulgaria (with a lag of 2 years), in Ukraine (with a lag of 5 years) ); average - in Latvia and Lithuania (without time lag), in Poland (with a lag of 1 year), in Estonia, Slovakia and Slovenia (with a lag of 2 years), in the Russian Federation (with a lag of 3 years). The character of the relationship for 7 countries in the study sample is inverse, for 4 countries - direct;

- the impact of GERD share financed by the private non-profit sector on GDP per capita: high - in Bulgaria (without time lag), in Latvia and the Czech Republic (with a lag of 1 year), in Estonia and Slovakia (with a lag of 2 years), in Lithuania (with a lag of 3 years), in Poland (with a lag of 5 years); average - in Slovenia (with a lag of 1 year), in Romania (with a lag of 2 years), in Hungary (with a time lag of 3 years). The character of the relationship for 5 countries in the study sample is inverse, for 5 countries - direct;

- the impact of GERD share financed by foreign sources on GDP per capita: high - in Romania, Hungary and the Czech Republic (with a lag of 2 years), in Bulgaria, Poland, the Russian Federation, Slovakia and Slovenia (with a lag of in 3 years); average - in Latvia and Ukraine (with a lag of 1 year), in Estonia (with a lag of 2 years), in Lithuania (with a lag of 3 years). The character of the relationship for 11 countries in the study sample is direct, for 1 country - inverse.

Therefore, we test the hypothesis regarding the negative impact of GERD share financed by the government sector, on the country's economic growth. We build a regression model for panel data for the studied countries for the period from 2007 to 2017 to confirm this hypothesis.

Since the economic growth (change of GDP per capita in \% to the previous year) (Table 7) cannot be estimated only by GERD share financed by the government sector (Table 2), we will introduce benchmarks into the model that are important macroeconomic determinants, namely:

1) net outflows of the direct foreign investments (\% of GDP) (Table 11):

Table 11. Net outflows of foreign direct investment (\% of GDP)

\begin{tabular}{|l|c|c|c|c|c|c|c|c|c|c|c|}
\hline \multicolumn{1}{|c|}{ Country } & $\mathbf{2 0 0 7}$ & $\mathbf{2 0 0 8}$ & $\mathbf{2 0 0 9}$ & $\mathbf{2 0 1 0}$ & $\mathbf{2 0 1 1}$ & $\mathbf{2 0 1 2}$ & $\mathbf{2 0 1 3}$ & $\mathbf{2 0 1 4}$ & $\mathbf{2 0 1 5}$ & $\mathbf{2 0 1 6}$ & $\mathbf{2 0 1 7}$ \\
\hline Bulgaria & 2,19 & 2,05 & 0,70 & 1,16 & 0,86 & 0,76 & 0,63 & 1,55 & 0,21 & 1,56 & 0,88 \\
\hline Estonia & 10,92 & 5,15 & 6,90 & 6,31 & $-5,86$ & 5,53 & 3,37 & 4,24 & $-2,50$ & 1,52 & 2,36 \\
\hline Latvia & 2,49 & 0,96 & $-0,74$ & 0,34 & 0,38 & 0,57 & 1,63 & 2,14 & 0,54 & 0,82 & 1,94 \\
\hline Lithuania & 2,20 & 1,16 & 1,61 & 0,29 & 1,88 & 0,98 & 0,71 & 1,12 & 0,86 & 1,89 & 1,22 \\
\hline Poland & 1,77 & 0,87 & 1,35 & 1,99 & 0,91 & 0,27 & $-0,65$ & 1,25 & 1,03 & 2,95 & 0,75 \\
\hline $\begin{array}{l}\text { Russian } \\
\text { Federation }\end{array}$ & 3,45 & 3,35 & 3,54 & 3,45 & 3,26 & 2,21 & 3,77 & 2,77 & 1,62 & 1,74 & 2,33 \\
\hline Romania & 0,38 & 0,15 & 0,01 & 0,14 & 0,03 & $-0,12$ & $-0,03$ & 0,13 & 2,16 & 0,67 & 0,18 \\
\hline Slovakia & 1,90 & 0,52 & 2,80 & 1,37 & 2,73 & $-1,31$ & 1,29 & 0,28 & 1,60 & 4,54 & 1,57 \\
\hline Slovenia & 4,62 & 2,40 & 0,68 & 0,41 & $-0,03$ & $-1,22$ & 0,07 & 0,43 & 0,76 & 1,07 & 1,30 \\
\hline Hungary & 48,78 & 46,57 & $-2,88$ & $-18,84$ & 6,22 & 6,19 & $-2,85$ & 6,57 & $-6,55$ & 52,31 & $-10,27$ \\
\hline Ukraine & 0,68 & 0,44 & 0,10 & 0,51 & 0,12 & 0,56 & 0,23 & 0,41 & 0,04 & 0,19 & 0,21 \\
\hline
\end{tabular}


Continued Table 11

\begin{tabular}{|l|c|c|c|c|c|c|c|c|c|c|c|}
\hline $\begin{array}{l}\text { Czech } \\
\text { Republic }\end{array}$ & 2,56 & 2,78 & 1,61 & 2,53 & 0,70 & 1,57 & 3,70 & 1,96 & 1,99 & 1,61 & 4,35 \\
\hline
\end{tabular}

Source: developed by the authors based on WorldBank Data, Foreign direct investment, net outflows, 2007-2017.

2) net inflows of foreign direct investment (\% of GDP) (Table 12):

Table 12. Net inflows of foreign direct investment (\% of GDP)

\begin{tabular}{|l|c|c|c|c|c|c|c|c|c|c|c|}
\hline \multicolumn{1}{|c}{ Country } & $\mathbf{2 0 0 7}$ & $\mathbf{2 0 0 8}$ & $\mathbf{2 0 0 9}$ & $\mathbf{2 0 1 0}$ & $\mathbf{2 0 1 1}$ & $\mathbf{2 0 1 2}$ & $\mathbf{2 0 1 3}$ & $\mathbf{2 0 1 4}$ & $\mathbf{2 0 1 5}$ & $\mathbf{2 0 1 6}$ & $\mathbf{2 0 1 7}$ \\
\hline Bulgaria & 31,24 & 18,92 & 7,51 & 3,64 & 3,66 & 3,32 & 3,58 & 1,92 & 4,34 & 2,77 & 3,47 \\
\hline Estonia & 15,28 & 7,69 & 9,45 & 13,17 & 4,78 & 7,71 & 4,34 & 6,65 & $-3,10$ & 3,86 & 6,36 \\
\hline Latvia & 8,78 & 4,02 & $-0,57$ & 2,00 & 5,38 & 3,84 & 3,27 & 3,32 & 3,00 & 1,20 & 3,76 \\
\hline Lithuania & 6,55 & 3,61 & $-0,96$ & 2,98 & 4,33 & 1,58 & 1,54 & 0,74 & 2,52 & 2,24 & 2,50 \\
\hline Poland & 5,83 & 2,73 & 3,19 & 3,84 & 3,50 & 1,47 & 0,15 & 3,63 & 3,15 & 3,88 & 2,24 \\
\hline $\begin{array}{l}\text { Russian } \\
\text { Federation }\end{array}$ & 4,30 & 4,50 & 2,99 & 2,83 & 2,68 & 2,29 & 3,01 & 1,07 & 0,50 & 2,54 & 1,81 \\
\hline Romania & 5,79 & 6,38 & 2,66 & 1,93 & 1,29 & 1,78 & 2,02 & 1,94 & 2,43 & 3,32 & 2,81 \\
\hline Slovakia & 5,85 & 4,62 & 1,71 & 2,35 & 5,49 & 1,88 & 1,02 & $-0,36$ & 1,72 & 5,29 & 4,44 \\
\hline Slovenia & 3,93 & 1,95 & $-0,69$ & 0,66 & 1,70 & 0,07 & 0,21 & 2,04 & 4,02 & 3,24 & 2,47 \\
\hline Hungary & 50,46 & 47,50 & $-2,14$ & $-15,84$ & 7,61 & 8,44 & $-2,65$ & 9,29 & $-4,23$ & 54,65 & $-8,50$ \\
\hline Ukraine & 7,15 & 5,95 & 4,07 & 4,74 & 4,42 & 4,65 & 2,46 & 0,63 & 3,35 & 3,69 & 2,52 \\
\hline $\begin{array}{l}\text { Czech } \\
\text { Republic }\end{array}$ & 7,30 & 3,74 & 2,56 & 4,90 & 1,84 & 4,55 & 3,51 & 3,89 & 0,91 & 5,56 & 5,20 \\
\hline
\end{tabular}

Source: developed by the authors based on WorldBank Data, Foreign direct investment, net inflows, 2007-2017.

3) share of labour resources (\% of the total population aged 15-64) (Table 13):

Table 13. The share of labor resources (\% of the total population aged 15-64)

\begin{tabular}{|l|c|c|c|c|c|c|c|c|c|c|c|}
\hline \multicolumn{1}{|c|}{ Country } & $\mathbf{2 0 0 7}$ & $\mathbf{2 0 0 8}$ & $\mathbf{2 0 0 9}$ & $\mathbf{2 0 1 0}$ & $\mathbf{2 0 1 1}$ & $\mathbf{2 0 1 2}$ & $\mathbf{2 0 1 3}$ & $\mathbf{2 0 1 4}$ & $\mathbf{2 0 1 5}$ & $\mathbf{2 0 1 6}$ & $\mathbf{2 0 1 7}$ \\
\hline Bulgaria & 66,72 & 68,31 & 67,57 & 66,72 & 65,99 & 67,07 & 68,37 & 69,03 & 69,40 & 68,80 & 71,48 \\
\hline Estonia & 73,23 & 74,33 & 74,18 & 73,99 & 74,84 & 74,97 & 75,27 & 75,40 & 76,80 & 77,63 & 78,89 \\
\hline Latvia & 72,73 & 74,33 & 73,72 & 73,18 & 73,13 & 74,67 & 74,18 & 74,51 & 75,71 & 76,45 & 77,27 \\
\hline Lithuania & 67,93 & 68,43 & 69,63 & 70,33 & 71,51 & 71,99 & 72,55 & 73,75 & 74,09 & 75,55 & 76,10 \\
\hline Poland & 63,18 & 63,85 & 64,68 & 65,58 & 65,98 & 66,71 & 67,21 & 68,08 & 68,38 & 69,10 & 69,85 \\
\hline $\begin{array}{l}\text { Russian } \\
\text { Federation }\end{array}$ & 72,69 & 73,00 & 72,85 & 72,73 & 73,06 & 73,16 & 73,19 & 73,43 & 73,68 & 74,24 & 74,15 \\
\hline Romania & 62,78 & 62,62 & 62,79 & 64,66 & 63,89 & 64,68 & 64,83 & 65,55 & 65,91 & 65,54 & 67,40 \\
\hline Slovakia & 68,29 & 68,83 & 68,43 & 68,65 & 68,77 & 69,50 & 69,90 & 70,27 & 70,95 & 71,95 & 72,20 \\
\hline Slovenia & 71,41 & 71,85 & 71,70 & 71,76 & 70,77 & 70,89 & 70,79 & 70,99 & 71,64 & 71,54 & 74,24 \\
\hline Hungary & 61,52 & 61,14 & 61,16 & 61,82 & 62,29 & 63,49 & 64,33 & 66,60 & 68,37 & 69,95 & 71,09 \\
\hline Ukraine & 66,63 & 66,50 & 66,40 & 66,44 & 66,79 & 66,44 & 67,27 & 65,83 & 66,25 & 66,25 & 66,48 \\
\hline $\begin{array}{l}\text { Czech } \\
\text { Republic }\end{array}$ & 69,92 & 69,69 & 70,04 & 70,12 & 70,45 & 71,48 & 72,80 & 73,53 & 74,13 & 75,19 & 76,11 \\
\hline
\end{tabular}
2017.

Source: developed by the authors based on WorldBank Data, Labor force participation rate, 2007 -

4) inflation rate index (GDP deflator, \%) (Table 14): 
Table 14. Inflation rate index (GDP deflator, $\%$ )

\begin{tabular}{|c|c|c|c|c|c|c|c|c|c|c|c|}
\hline Country & $\mathbf{2 0 0 7}$ & $\mathbf{2 0 0 8}$ & $\mathbf{2 0 0 9}$ & $\mathbf{2 0 1 0}$ & $\mathbf{2 0 1 1}$ & $\mathbf{2 0 1 2}$ & $\mathbf{2 0 1 3}$ & $\mathbf{2 0 1 4}$ & $\mathbf{2 0 1 5}$ & $\mathbf{2 0 1 6}$ & $\mathbf{2 0 1 7}$ \\
\hline Bulgaria & 11,09 & 8,13 & 4,05 & 1,11 & 5,98 & 1,56 & $-0,70$ & 0,46 & 2,21 & 2,25 & 3,40 \\
\hline Estonia & 12,42 & 6,90 & $-0,18$ & 1,83 & 5,39 & 4,02 & 4,04 & 2,95 & 1,12 & 1,71 & 3,64 \\
\hline Latvia & 20,13 & 11,73 & $-9,73$ & $-0,40$ & 6,40 & 3,62 & 1,64 & 1,78 & 0,00 & 0,86 & 2,98 \\
\hline Lithuania & 8,57 & 9,70 & $-3,30$ & 2,27 & 5,38 & 2,78 & 1,35 & 0,92 & 0,09 & 1,61 & 4,25 \\
\hline Poland & 3,71 & 3,88 & 3,77 & 1,66 & 3,23 & 2,35 & 0,29 & 0,50 & 0,77 & 0,31 & 1,83 \\
\hline $\begin{array}{c}\text { Russian } \\
\text { Federation }\end{array}$ & 13,84 & 18,01 & 1,97 & 14,19 & 24,81 & 9,04 & 5,39 & 7,35 & 7,59 & 3,17 & 5,36 \\
\hline Romania & 15,82 & 16,02 & 4,09 & 3,54 & 3,78 & 4,01 & 3,39 & 1,74 & 2,61 & 2,46 & 4,68 \\
\hline Slovakia & 1,12 & 2,86 & $-1,16$ & 0,49 & 1,67 & 1,27 & 0,51 & $-0,19$ & $-0,22$ & $-0,51$ & 1,21 \\
\hline Slovenia & 4,18 & 4,47 & 3,40 & $-1,03$ & 1,04 & 0,48 & 1,60 & 0,46 & 1,01 & 0,75 & 1,58 \\
\hline Hungary & 5,44 & 4,79 & 4,19 & 2,38 & 2,18 & 3,20 & 2,98 & 3,59 & 2,46 & 0,97 & 3,70 \\
\hline Ukraine & 23,10 & 28,58 & 13,02 & 13,92 & 14,20 & 7,79 & 4,34 & 15,90 & 38,88 & 17,10 & 22,08 \\
\hline $\begin{array}{c}\text { Czech } \\
\text { Republic }\end{array}$ & 3,52 & 2,05 & 2,60 & $-1,43$ & 0,02 & 1,46 & 1,43 & 2,48 & 1,17 & 1,27 & 1,44 \\
\hline
\end{tabular}

Source: developed by the authors based on WorldBank Data, Inflation, GDP deflator, 2007-2017.

The regression model for estimating the impact of GERD share financed by the government sector, net inflows and outflows of foreign direct investment, labour resources and inflation on GDP dynamics per capita can be represented as:

$$
\mathrm{GDP}_{G S}=\alpha+\beta_{1}(\mathrm{GS})+\beta_{2}(\mathrm{II})++\beta_{3}(\mathrm{IO})+\beta_{4}(\mathrm{~L})+\beta_{5}(\mathrm{I})+\mathrm{u}+\varepsilon
$$

where $\alpha$ - constant; $\beta$ - coefficients obtained by the least-squares method (MLS); $u$ - standard error for individual effects; $\varepsilon$ - standard error; GDP - annual change of GDP per capita (\% to the previous year); GS - the share of GERD financed by the government sector ( $\%$ of GERD); IO - net outflows of foreign direct investment ( $\%$ of GDP); II - net inflows of foreign direct investment ( $\%$ of GDP); $L$ - the share of labour resources (\% of the total population 15-64 years); I - inflation rate (GDP deflator, \%).

Table 15 demonstrates the descriptive statistical features of the model variables. We evaluate a regression model with fixed effects for the studied variables. Regression «within» is a method for estimating the regression model coefficients with deterministic individual effects (FE) and is an initial regression model, rewritten in terms of deviations from the average time variables, eliminating individual effects that are not observed. Each object of the sample is introduced with its own constant. Thus, the model considers the existing heterogeneity, which is not observed. The evaluation of the model is performed by the least-squares method (MLS).

Table 15. Descriptive statistics of variables of the regression equation

\begin{tabular}{|c|c|c|c|c|}
\hline Variable & Mean & Std. Dev. & Min & Max \\
\hline GDPGS $_{\text {GS }}$ & 2.27 & 4.69 & -14.38 & 12.41 \\
\hline IO & 43.54 & 12.38 & 19.90 & 70.30 \\
\hline II & 2.31 & 7.76 & -18.84 & 52.31 \\
\hline L & 4.59 & 8.32 & -15.84 & 54.65 \\
\hline I & 69.94 & 4.06 & 61.14 & 78.89 \\
\hline
\end{tabular}

Mean - average value; Std. Dev. - standard deviation; Min - minimum value; Max - maximum value.

Source: developed by the authors. 
Table 16 demonstrates the assessment results of the impact of GERD share financed by the government sector on the annual change of GDP per capita.

Table 16. The assessment results of the impact of GERD share financed by the government sector on the annual change of GDP per capita (regression model with fixed effects)

\begin{tabular}{|c|c|c|c|c|c|}
\hline GDPGS & Coef. & Std. Err. & $\mathrm{t}$ & $P>|t|$ & [95\% Conf. Interval] \\
\hline GS & -.1470456 & .0560063 & -2.63 & 0.010 & $-.2579833-.036108$ \\
\hline 10 & -.5379936 & .1463496 & -3.68 & 0.000 & $\begin{array}{lll}-827884 & -.2481033 \\
\end{array}$ \\
\hline II & .5473872 & .139454 & 3.93 & 0.000 & $.2711555 \quad .8236188$ \\
\hline $\mathrm{L}$ & .3296943 & .2301173 & 1.43 & 0.155 & $-.1261237 \quad .7855123$ \\
\hline 1 & .3194813 & .0856522 & 3.73 & 0.000 & $.1498207 \quad .4891418$ \\
\hline Const. & -17.17244 & 17.42995 & -0.99 & 0.327 & $-51.69783 \quad 17.35294$ \\
\hline \multicolumn{6}{|c|}{ Prob $>F=0,0000 ; \quad$ R-squared $=0,2848$} \\
\hline
\end{tabular}

Coef. - evaluations of coefficients $\beta$, obtained by the MLS; Std. Err. - standard deviations of evaluations; $t$ - $t$-statistics; $\mathrm{P}$ - the level of t-criterion significance; Conf. Interval - confidence interval; Const. - constant; Sigma_u - standard error for individual effects; sigma_e - standard error for $\varepsilon$.

Source: developed by the authors.

The level of significance of the $t$-criterion for the coefficient $L$ (labour resources) exceeds 0.05 , so it cannot be statistically significant (the probability of error acceptance of the hypothesis is $15.5 \%$ ). Other indices are statistically significant. Moreover, the model requires only the noncorrelation of $\varepsilon$ and $X$ for the ability of MLS estimates with deterministic individual effects. The correlation between $X$ and $u$ is assumed, which is a manifestation of the FE-model flexibility. In our case corr $\left(u_{-} \mathrm{i}, \mathrm{Xb}\right)=-0.6232$.

The R-squared index is not very high (0.2848), but it can be explained by the fact that this model has significant individual differences (as opposed to dynamic), which ultimately indicates the necessity to consider the individual effects and the ability of the selected model.

At the same time, the regression model with fixed effects does not allow to estimate the coefficients for time-invariant regressors since they are eliminated from the model after the transformation «within». Therefore, there is a need for a parallel study and regression model with random effects (RE) (Table 17). The generalized least squares method (GLS) performs estimation.

Table 17. Results of the assessment of the GERD share impact financed by the government sector on the annual change of GDP per capita (regression model with random effects)

\begin{tabular}{|c|c|c|c|c|c|}
\hline $\mathrm{GDP}_{\mathrm{GS}}$ & Coef. & Std. Err. & $\mathrm{z}$ & $P>|z|$ & [95\% Conf. Interval] \\
\hline GS & -.0370614 & .034415 & -1.0769 & .282 & $-.1045135 \quad .0303907$ \\
\hline 10 & -.4166524 & .1314194 & -3.1704 & $1.5 \mathrm{e}-03$ & $-.6742297 \quad-.159075$ \\
\hline II & .4173445 & .1238644 & 3.36937 & $7.5 \mathrm{e}-0.4$ & $.1745748 \quad 6601142$ \\
\hline $\mathrm{L}$ & .0865935 & .1009912 & .857436 & .391 & -.1113456 .2845325 \\
\hline $\mathrm{T}$ & .0888773 & 669654 & 1.32721 & .184 & $\begin{array}{ll}.0423725 & .2201272\end{array}$ \\
\hline Const. & -3.546779 & 7.499268 & -.47295 & .636 & $-18.24507 \quad 11.15152$ \\
\hline
\end{tabular}

Prob>chi2 =0,0058; Wald chi2(5) $=16,39 ; \quad$ corr $($ u_i, X) $=0$ (assumed)

Sigma_u $=0$; $\quad$ sigma_e $=4,107506$

Coef. - evaluations of coefficients $\beta$; Std. Err. - standard deviations of evaluations; $P$ - the level of z-criterion significance; Conf. Interval - confidence interval; Const. - constant; Sigma_u - standard error for individual effects; sigma_e - standard error for $\varepsilon$.

Source: developed by the authors. 
Compared to the previous model, most of the coefficients are not statistically significant (the significance level $P>|z|$ exceeds 0.05 ). The index corr $\left(u_{-} i, X\right)=0$ (assumed) reflects an important hypothesis underlying the model - regressors should not correlate with random effects that are not observed. Also, the interpretation of this model should not be based on the R-sq index, since it is not an informative means of checking the model ability in the regression, estimated using the generalized least squares method. The Wald statistical test proves the significance of the regression in this case. However, the index Wald chi2 $(5)=16.39$ is a low value, Prob> chi2 $=0.0058$. It is explained by the fact that the Wald test checks the hypothesis that all individual effects are equal to zero. Herewith, a regression model with random effects can only take place where the random effect does not correlate with regressors, which is often not performed.

It is advisable to compare the fixed effects regression model with a standard regression model using the Wald test, which checks the hypothesis regarding the zero equality of all individual effects, to select the adequate model. In particular, we obtain the following result: $F$ test that all $u_{-} i=0: F(11,115)=3.31$. Prob $>F=0.0006$. Since the significance level is $p$-level $<0.01$, the main hypothesis is not confirmed, and the fixed effects regression model is better suited for data description than the standard regression model.

Second, we compare the random effect model with the standard regression model using the BreuschPagan test. The Breusch-Pagan test is a test for the random individual effect. In the studied case, the $p$ level $>0.01$, i.e. the main hypothesis is confirmed, and the model with random effects describes the data worse than the standard regression model.

Third, it is reasonable to use the Hausman test to select an adequate model from the two formed ones (between FE and RE models). The test checks the main hypothesis $\mathrm{H} 0$ : corr (ui, Hit) $=0$ or ui can be considered as random effects. And the alternative - HA: corr (ai, Hit) $\neq 0$ or ui should be considered deterministic. The results of the Hausman test indicate that the $p$-level is $<0.01$, so the main hypothesis is not confirmed. It enables to conclude that in this study, it is advisable to use a regression model with fixed individual effects.

Therefore, the regression equation constructed according to the accepted model with fixed effects is:

$$
\mathrm{GDP}_{\mathrm{GS}}=-0,15 \mathrm{GS}+0,55 I I-0,5410+0,33 L+0,32 I-10,03
$$

The evaluated coefficient $\beta$ for GERD $_{G O V}$ is statistically significant (the probability of erroneous acceptance of the hypothesis is 1\%) and negative, indicating an inverse relationship between GDP and GS. It is empirically confirmed that with the growth of GERD financed by the government sector (in total GERD) by $1 \%$, the annual growth (change) of GDP per capita will decrease by $0.15 \%$.

Therefore, the urgent problem is to reduce GERD share financed by the government sector in the structure of GERD and the increase in the share of other financing sources for innovative development.

The impact of financial support for country's innovative development on its economic growth was examined through the business sector according to the dynamic model of panel data evaluation (ArellanoBond linear dynamic panel-data estimation (Arellano \& Bond, 1991)). It is used to study the economic phenomena evolution, avoiding the displacement of aggregation. Linear dynamic models of these panels include lags of the dependent variable as covariates and contain unnoticed fixed or random effects at the panel level. It means that the dynamic model makes it possible to consider how the share of GERD financed by the business sector of the previous period affects the current situation).

The dynamic panel data model has the following form (Arellano - Bond): 


$$
y_{i t}=\sum_{j=1}^{p} \alpha_{j} y_{i, t-j}+x_{i t} \beta_{1}+w_{i t} \beta_{2}+u_{i}+\varepsilon_{i t}
$$

where $a_{j}$ - p-parameters to be evaluated; $\sum_{j=1}^{p} \alpha_{j} y_{i, t-j}$ - lagged dependent variable; $x_{i t}$ - vector of strictly exogenous covariates; $w_{i t}$ - vector of predetermined and endogenous covariates; $u_{i}$ - panel level effects; $\varepsilon_{\text {it }}-$ i.i.d $\left(0, \sigma_{\varepsilon}^{2}\right) ; i=1, \ldots, N ; t=1, \ldots, T_{i}$.

The dynamic model, achieved by introducing lagged variables, leads to significant changes in the interpretation of the regression equation. Regressors describe a complete set of information that determines the observed values of the dependent variable without a lagged dependent variable. The prehistory of the regressors is considered with the introduction of the lagged variable. Therefore, it causes any influence on the measurement process. In this case, since both MLS and FE-estimates are incapable of the final values of $T$, the instrumental variables method or the generalized method of moments (GMM) is used to obtain adequate estimates in this model.

Table 18 provide descriptive statistical features of the variables of the model for estimating the impact of GERD share financed by the business sector on GDP dynamics per capita.

Table 18. Descriptive statistics of regression equation variables

\begin{tabular}{|c|c|c|c|c|}
\hline Variable & Mean & Std. Dev. & Min & Max \\
\hline GDPBS $_{\text {BS }}$ & 2.27 & 4.69 & -14.38 & 12.41 \\
\hline BS & 37.39 & 11,70 & 16,70 & 69,20 \\
\hline IO & 2.31 & 7.76 & -18.84 & 52.31 \\
\hline II & 4.59 & 8.32 & -15.84 & 54.65 \\
\hline L & 69.94 & 4.06 & 61.14 & 78.89 \\
\hline I & 4.75 & 6.54 & -9.73 & 38.88 \\
\hline
\end{tabular}

Mean - average value; Std. Dev. - standard deviation; Min - minimum value; Max - maximum value.

Source: developed by the authors.

The results of estimating the impact of GERD share financed by the business sector on the annual change of GDP per capita are shown in Table 19. One should also notice that the dynamic model for estimating the Arellano-Bond panel data considers the fact that some regressors in the model are not completely exogenous. They can be influenced by the past and the present value of the dependent variable (GDP dynamics per capita). In our case, only the labour resources index (economically active population) can be considered a completely exogenous variable. Other variables are considered endogenous.

Table 19. Results of estimating the impact of GERD share financed by the business sector on the annual change of GDP per capita according to the dynamic regression model of panel data estimation

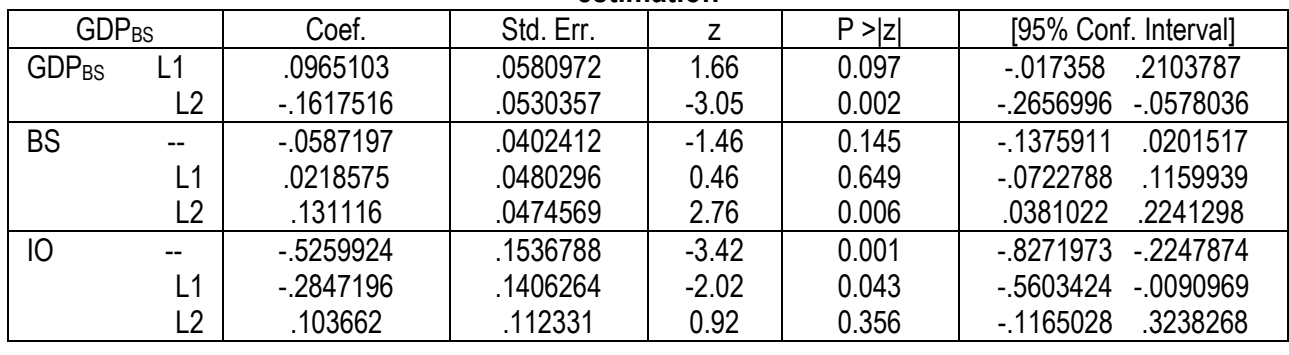


Continued Table 19

\begin{tabular}{|c|c|c|c|c|c|c|}
\hline$\|$ & $\begin{array}{l}-- \\
\text { L1 } \\
\text { L2 }\end{array}$ & $\begin{array}{l}.4951182 \\
.2744093 \\
-.0875951\end{array}$ & $\begin{array}{l}.1450695 \\
.131297 \\
.1092494\end{array}$ & $\begin{array}{r}3.41 \\
2.09 \\
-0.80\end{array}$ & $\begin{array}{l}0.001 \\
0.037 \\
0.423\end{array}$ & $\begin{array}{cc}.2107873 & .7794492 \\
.017072 & .5317466 \\
-.3017201 & .1265298\end{array}$ \\
\hline $\mathrm{L}$ & & .5681057 & .1632869 & 3.48 & 0.001 & $.2480694 \quad .8881421$ \\
\hline I & $\begin{array}{l}-- \\
\mathrm{L} 1 \\
\mathrm{~L} 2\end{array}$ & $\begin{array}{l}-.138876 \\
.1207087 \\
.035368\end{array}$ & $\begin{array}{l}.0531521 \\
.0498796 \\
.0430646\end{array}$ & $\begin{array}{l}-2.61 \\
2.42 \\
0.82\end{array}$ & $\begin{array}{l}0.009 \\
0.016 \\
0.411\end{array}$ & $\begin{array}{cc}-.2430523 & -.0346998 \\
.0229464 & .2184709 \\
-.0490371 & 1197732\end{array}$ \\
\hline & & -41.95952 & 11.20295 & -3.75 & 0.000 & $-63.9169-20.00215$ \\
\hline
\end{tabular}

Coef. - estimates of coefficients $\beta$; Std. Err. - standard errors of estimates; P - significance level; Conf. Interval confidence interval; Const. - constant.

Source: developed by the authors.

The Wald test value and the index Prob> chi2 $=0.0000$ indicate the adequacy of the model. It is also necessary to check the Sargan test for the validity of instruments, over-identification of restrictions (Sargan test of overidentifying restrictions) to confirm the quality of the model. The test results are as follows:

Sargan test of overidentifying restrictions

$\mathrm{HO}$ : overidentifying restrictions are valid

chi2 $(68)=109.6984$

Prob $>$ chi2 $=0.0010$

Thus, the regression equation formed according to the dynamic model for estimating Arellano-Bond panel data is:

$$
\begin{gathered}
\mathrm{GDP}_{\mathrm{BS}} \text { it }=-41.96-0,16 \mathrm{GDP}_{\mathrm{BS} \text { i,t-2 }}+0,13 \mathrm{BS} \mathrm{i}_{\mathrm{i}, \mathrm{t}-2}+0,5 \mathrm{ll}_{\mathrm{it}}-0,531 \mathrm{O}_{\mathrm{it}}+ \\
0,57 \mathrm{~L}_{\mathrm{it}}-0,13 \mathrm{l}_{\mathrm{it}}
\end{gathered}
$$

The estimated coefficient $\beta$ for BS index is statistically significant (the probability of erroneous acceptance of the hypothesis is $0.6 \%$ ) and positive. It indicates a direct relationship between GDP and BS.

It is empirically confirmed that with the growth of the share of GERD financed by the business sector (in total GERD) by $1 \%$, the annual growth (change) of GDP per capita will increase by an average of $0.13 \%$ over time 2 years.

The impact of GERD financed by the higher education sector on the economic growth change was estimated similarly to the dynamic model for Arellano-Bond panel data. It should be emphasized that net inflows and outflows of foreign direct investment and the inflation level are not completely exogenous variables. Instead, the share of GERD financed by the higher education sector and the labour force index considered being exogenous. Table 20 demonstrates the descriptive statistical features of the model variables.

Table 20. Descriptive statistics of regression equations

\begin{tabular}{|c|c|c|c|c|}
\hline Variable & Mean & Std. Dev. & Min & Max \\
\hline GDPES $_{\text {ES }}$ & 2.27 & 4.69 & -14.38 & 12.41 \\
\hline ES & 1.06 & 1.07 & 0 & 6.7 \\
\hline IO & 2.31 & 7.76 & -18.84 & 52.31 \\
\hline II & 4.59 & 8.32 & -15.84 & 54.65 \\
\hline I & 69.94 & 4.06 & 61.14 & 78.89 \\
\hline
\end{tabular}

Mean - average value; Std. Dev. - standard deviation; Min - minimum value; Max - maximum value.

Source: developed by the authors. 
Table 21 shows the estimating results of the impact made by the share of GERD financed by the higher education sector, on the annual change of GDP per capita.

Table 21. The estimating results of the impact made by the share of GERD financed by the higher education sector on the annual change of GDP per capita (dynamic regression model for

estimating Arellano-Bond panel data)

\begin{tabular}{|c|c|c|c|c|c|c|}
\hline \multicolumn{2}{|c|}{$\mathrm{GDP}_{\mathrm{ES}}$} & Coef. & Std. Err. & $\mathrm{z}$ & $P>|z|$ & [95\% Conf. Interval] \\
\hline \multirow[t]{3}{*}{$\overline{G D P E S}$} & L1 & .1069932 & .0591636 & 1.81 & 0.071 & $-.0089653 \quad .2229516$ \\
\hline & L2 & -.2209384 & .0528091 & -4.18 & 0.000 & $\begin{array}{ll}-.3244424 & -.1174345\end{array}$ \\
\hline & L3 & 119097 & .0518674 & 2.30 & 0.022 & $\begin{array}{ll}.0174388 & .2207551\end{array}$ \\
\hline \multicolumn{2}{|l|}{ ES } & -.7808659 & .4050294 & -1.93 & 0.054 & $\begin{array}{ll}-1.574709 & .0129771\end{array}$ \\
\hline \multirow[t]{3}{*}{10} & - & -.4138238 & .1569283 & -2.64 & 0.008 & $\begin{array}{ll}-.7213975 & -.10625\end{array}$ \\
\hline & L1 & -.2349568 & .1453393 & -1.62 & 0.106 & $\begin{array}{ll}-.5198167 & .049903\end{array}$ \\
\hline & $\mathrm{L} 2$ & -.0373236 & .1098567 & -0.34 & 0.734 & -.2526387 \\
\hline \multirow[t]{3}{*}{ II } & -- & .3758285 & .1485245 & 2.53 & 0.011 & $.0847259 \quad .6669311$ \\
\hline & L1 & .2283379 & .1365329 & 1.67 & 0.094 & $-.0392617 \quad .4959375$ \\
\hline & L2 & .0535059 & .1072776 & 0.50 & 0.618 & $-.1567544 \quad .2637661$ \\
\hline \multicolumn{2}{|l|}{$\mathrm{L}$} & .5836773 & .1646639 & 3.54 & 0.000 & .260942 .9064126 \\
\hline \multirow[t]{3}{*}{-} & - & -.1640632 & .0582908 & -2.81 & 0.005 & $-.2783111 \quad-.0498153$ \\
\hline & L1 & .1610771 & .0521704 & 3.09 & 0.002 & $\begin{array}{ll}.0588251 & .2633292\end{array}$ \\
\hline & L2 & .0496852 & .044856 & 1.11 & 0.268 & $\begin{array}{ll}-.038231 \quad .1376014\end{array}$ \\
\hline \multicolumn{2}{|l|}{ Const. } & -39.00784 & 11.49981 & -3.39 & 0.001 & $-61.54706-16.46862$ \\
\hline \multicolumn{7}{|c|}{ Wald chi2(11) $=73.96$ Prob $>$ chi2 $=0.0000$} \\
\hline
\end{tabular}

Coef. - estimates of coefficients $\beta$; Std. Err. - standard errors of estimates; P - significance level; Conf. Interval confidence interval; Const. - constant.

Source: developed by the authors.

The Wald test value and the index Prob> chi2 $=0.0000$ indicate the adequacy of the model. It is also necessary to check the Sargan test for validity of instruments, overidentification of restrictions (Sargan test of overidentifying restrictions) to confirm the quality of the model. The test results are as follows:

Sargan test of overidentifying restrictions

$\mathrm{HO}$ : overidentifying restrictions are valid

$\operatorname{chi} 2(67)=94.14016$

Prob $>$ chi2 $=0.0161$

Thus, the regression equation based on the dynamic model of estimation of Arellano-Bond panel data for evaluating the impact made by the share of GERD financed by the higher education sector on the dynamics of GDP per capita is as follows:

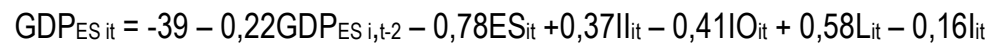

The estimated coefficient $\beta$ for the ES index is statistically significant (the probability of erroneous acceptance of the hypothesis is 5.4\%) and negative. It indicates an inverse relationship between GDP and ES. It is empirically confirmed that with the growth of GERD financed by the higher education sector (in total GERD) by $1 \%$, the annual increase (change) in GDP per capita will decrease by an average of $0.78 \%$.

The impact of R\&D financing from foreign sources on the economic growth change was estimated according to the dynamic regression model for panel data. Table 22 presents descriptive statistical features of model variables. An exogenous variable is an indicator of labour resources. Other variables are endogenous. 
Table 22. Descriptive statistics of regression equation variables

\begin{tabular}{|c|c|c|c|c|}
\hline Variable & Mean & Std. Dev. & Min & Max \\
\hline GDPFS & 2.27 & 4.69 & -14.38 & 12.41 \\
\hline FS & 17.59 & 12.13 & 2,30 & 51,6 \\
\hline IO & 2.31 & 7.76 & -18.84 & 52.31 \\
\hline II & 4.59 & 8.32 & -15.84 & 54.65 \\
\hline I & 69.94 & 4.06 & 61.14 & 78.89 \\
\hline
\end{tabular}

Mean - average value; Std. Dev. - standard deviation; Min - minimum value; Max - maximum value.

Source: developed by the authors.

Table 23 shows the estimating results of the impact made by GERD share financed by foreign sources on the annual change in GDP per capita.

Table 23. The estimating results of the impact made by GERD share financed by foreign sources on the annual change of GDP per capita (dynamic regression model for estimating Arellano-Bond panel data)

\begin{tabular}{|c|c|c|c|c|c|c|}
\hline \multirow{2}{*}{\multicolumn{2}{|c|}{$\mathrm{GDP}_{\mathrm{FS}}$}} & \multirow{2}{*}{\multicolumn{4}{|c|}{ Std. Err. }} & \multirow{2}{*}{ [95\% Conf. Interval] } \\
\hline & & & & & $P>|z|$ & \\
\hline \multirow[t]{3}{*}{ GDPIS } & L1 & .0555692 & .0602802 & 0.92 & 0.357 & $-0625779 \quad .1737162$ \\
\hline & L2 & -.226979 & .0549697 & -4.13 & 0.000 & $\begin{array}{ll}-.3347176 & -.1192403\end{array}$ \\
\hline & L3 & .0816833 & .050087 & 1.63 & 0.103 & $-.0164854 \quad .179852$ \\
\hline \multirow[t]{4}{*}{ FS } & -- & .0960544 & .0393402 & 2.44 & 0.015 & .0189491 . 1731597 \\
\hline & L1 & .0012333 & .0376868 & 0.03 & 0.974 & $\begin{array}{ll}-.0726314 & .075098\end{array}$ \\
\hline & L2 & -.0532726 & .0451401 & -1.18 & 0.238 & $-.1417456 \quad .0352003$ \\
\hline & L3 & .1063822 & .039204 & 2.71 & 0.007 & $.0295438 \quad .1832207$ \\
\hline \multirow[t]{3}{*}{10} & - & -.4245147 & .1486766 & -2.86 & 0.004 & $-.7159156-.1331138$ \\
\hline & L1 & -.2690503 & .1359769 & -1.98 & 0.048 & $\begin{array}{ll}-.5355602 & -.0025404\end{array}$ \\
\hline & L2 & -.0974869 & .1176809 & -0.83 & 0.407 & $\begin{array}{ll}-.3281373 \quad .1331634 \\
\end{array}$ \\
\hline \multirow[t]{3}{*}{ II } & -- & .4023108 & 1398118 & 2.88 & 0.004 & $\begin{array}{ll}.1282847 & .6763368\end{array}$ \\
\hline & L1 & .2796181 & .1278812 & 2.19 & 0.029 & $.0289755 \quad .5302606$ \\
\hline & L2 & .1142443 & .1152294 & 0.99 & 0.321 & $-.1116012 \quad .3400899$ \\
\hline $\mathrm{L}$ & & 457108 & .1646031 & 2.78 & 0.005 & $\begin{array}{ll}1344918 & .7797241\end{array}$ \\
\hline \multirow[t]{3}{*}{ l } & -- & -.1013334 & .0529112 & -1.92 & 0.054 & $-.2050374 \quad .0023706$ \\
\hline & L1 & .1307945 & .0489385 & 2.67 & 0.008 & $.0348768 \quad .2267121$ \\
\hline & L2 & .0532723 & .0427883 & 1.25 & 0.213 & $-.0305911 \quad$ 1371358 \\
\hline Const. & & -33.97228 & 11.41806 & -2.98 & 0.003 & $-56.35127 \quad-11.59329$ \\
\hline
\end{tabular}

Coef. - estimates of coefficients $\beta$; Std. Err. - standard errors of estimates; P - significance level; Conf. Interval confidence interval; Const. - constant.

Source: developed by the authors

The Wald test value and the index Prob> chi2 $=0.0000$ indicate the adequacy of the model. It is also necessary to check the Sargan test for the validity of instruments, overidentification of restrictions (Sargan test of overidentifying restrictions) to confirm the quality of the model. The test results are as follows:

Sargan test of overidentifying restrictions

$\mathrm{HO}$ : overidentifying restrictions are valid

$\operatorname{chi} 2(65)=107.7804$

Prob $>$ chi2 $=0.0007$ 
Thus, the regression equation based on the dynamic model of estimation of Arellano-Bond panel data for evaluating the impact made by GERD share financed by the foreign sources on the dynamics of GDP per capita is as follows:

$$
\mathrm{GDP}_{\mathrm{FS}} \text { it }=-33,97-0,23 \mathrm{GDP}_{\mathrm{FS} i,-2}+0,1 \mathrm{FS}_{\mathrm{it}}+0,40 \mathrm{Il}_{\mathrm{it}}-0,42 \mathrm{IO}_{\mathrm{it}}+0,46 \mathrm{~L}_{\mathrm{it}}+0,13 \mathrm{l}_{\mathrm{i}, \mathrm{t}-\mathrm{1}}
$$

The estimated coefficient $\beta$ for the FS index is statistically significant (the probability of erroneous acceptance of the hypothesis is $1.5 \%$ ) and positive. It indicates the direct relationship between GDP and FS.

It is empirically confirmed that with the growth of GERD financed by the foreign sources (in total R\&D expenditure) by $1 \%$, annual growth (change) of GDP per capita will increase by an average of $0.1 \%$.

The impact of GERD financed by the private non-profit sector on changes in economic growth was evaluated. Descriptive statistical features of the model variables are given in Table 24. The estimating results of the impact made by the R\&D expenditures share financed by private non-profit sector on the annual change in GDP per capita are shown in Table 25.

Table 24. Descriptive statistics of regression equation variables

\begin{tabular}{|c|c|c|c|c|}
\hline Variable & Mean & Std. Dev. & Min & Max \\
\hline GDP $_{\text {NS }}$ & 2.27 & 4.69 & -14.38 & 12.41 \\
\hline NS & 0.26 & 0.29 & 0.00 & 1.40 \\
\hline IO & 2.31 & 7.76 & -18.84 & 52.31 \\
\hline II & 4.59 & 8.32 & -15.84 & 54.65 \\
\hline L & 69.94 & 4.06 & 61.14 & 78.89 \\
\hline I & 4.75 & 6.54 & -9.73 & 38.88 \\
\hline
\end{tabular}

Mean - average value; Std. Dev. - standard deviation; Min - minimum value; Max - maximum value.

Source: developed by the authors.

Table 25. The evaluating results of the impact of GERD share financed by the private non-profit sector on the annual change in GDP per capita (regression model with fixed effects)

\begin{tabular}{|c|c|c|c|c|c|}
\hline GDPNS $_{\text {N }}$ & Coef. & Std. Err. & $\mathrm{t}$ & $P>|t|$ & [95\% Conf. Interval] \\
\hline NS & -1.072111 & 1.770376 & -0.61 & 0.546 & $-4.578886 \quad 2.434664$ \\
\hline 10 & -.4434982 & 1455616 & -3.05 & 0.003 & $-.7318277 \quad-.1551686$ \\
\hline II & .4503416 & 1379064 & 3.27 & 0.001 & $.1771755 \quad .7235077$ \\
\hline $\mathrm{L}$ & .6182469 & 2071118 & 2.99 & 0.003 & .20799841 .028495 \\
\hline | & .3014415 & .0880239 & 3.42 & 0.001 & .127083 \\
\hline Const. & -43.16374 & 14.62434 & -2.95 & 0.004 & $-72.13175 \quad-14.19573$ \\
\hline \multicolumn{6}{|c|}{ Prob $>F=0,0000 ; \quad$ R-squared $=0.2443$} \\
\hline
\end{tabular}

Coef. - estimates of coefficients $\beta$, obtained by MLS; Std. Err. - standard errors of estimates; $\mathrm{t}$ - t-статистика; P significance level of t-criterion; Conf. Interval - confidence interval; Const. - constant; Sigma_u - standard error for individual effects; sigma_e - standard error for $\varepsilon$.

Source: developed by the authors.

The significance level of the t-criterion for GERD share financed by the private non-profit sector is 0.546. It shows the statistical insignificance of the regression coefficient obtained for this index in the model with fixed effects. Similarly, the regression coefficient for GERD share financed by the private nonprofit sector, calculated according to the model with random effects (significance level of t-criterion is 0.967), is not statistically significant. 
The estimating results of the impact made by GERD share financed by the private non-profit sector on the annual change in GDP per capita according to the dynamic regression model for estimating panel data (Arellano-Bloom) are shown in Table 26. Exogenous variables include labour force index and GERD financed by the private non-profit sector.

Table 26. The evaluating results of the impact made by GERD share financed by the private nonprofit sector on the annual change in GDP per capita (dynamic regression model for estimating Arellano-Bond panel data)

\begin{tabular}{|c|c|c|c|c|c|c|}
\hline \multicolumn{2}{|c|}{ GDPNS $_{\text {N }}$} & Coef. & Std. Err. & $z$ & $P>|z|$ & [95\% Conf. Interval] \\
\hline \multirow[t]{3}{*}{$\mathrm{GDP}_{\mathrm{NS}}$} & L1 & .1371998 & .0619449 & 2.21 & 0.027 & $.0353095 \quad .23909$ \\
\hline & L2 & -.2124495 & .054768 & -3.88 & 0.000 & $\begin{array}{ll}-.3025348 & -.1223642\end{array}$ \\
\hline & L3 & 1594017 & .0554552 & 2.87 & 0.004 & $.0681861 \quad .2506174$ \\
\hline \multirow[t]{3}{*}{ NS } & -- & -.1271217 & 1.043229 & -0.12 & 0.903 & $-1.843081 \quad 1.588837$ \\
\hline & L1 & 1.107747 & .9534241 & 1.16 & 0.245 & $-.4604966 \quad 2.67599$ \\
\hline & L2 & -1.33637 & .9127274 & -1.46 & 0.143 & $\begin{array}{ll}-2.837673 & .1649333\end{array}$ \\
\hline \multirow[t]{3}{*}{10} & -- & -.5194458 & .1639552 & -3.17 & 0.002 & $-.7891281 \quad-.2497635$ \\
\hline & L1 & -.283353 & .1508947 & -1.88 & 0.060 & $\begin{array}{ll}-.5315527 & -.0351533\end{array}$ \\
\hline & $\mathrm{L} 2$ & .0121102 & .1122692 & 0.11 & 0.914 & $-.1725562 \quad .1967765$ \\
\hline \multirow[t]{3}{*}{ II } & -- & .4925987 & .1552673 & 3.17 & 0.002 & $\begin{array}{ll}2372067 & .7479907\end{array}$ \\
\hline & L1 & .2973987 & .1424119 & 2.09 & 0.037 & $.063152 \quad .5316454$ \\
\hline & L2 & .0003093 & .1097056 & 0.00 & 0.998 & -1807589 \\
\hline$L$ & & .4413029 & .166959 & 2.64 & 0.008 & $.1666799 \quad .715926$ \\
\hline \multirow[t]{3}{*}{ I } & -- & -.2094483 & .0601701 & -3.48 & 0.000 & $-.3084193 \quad-.1104773$ \\
\hline & L1 & .1962349 & .052899 & 3.71 & 0.000 & . $1092238 \quad$.2832459 \\
\hline & L2 & .0390656 & .0461281 & 0.85 & 0.397 & $\begin{array}{ll}-.0368083 & .1149396 \\
\end{array}$ \\
\hline \multicolumn{2}{|l|}{ Const. } & -29.95317 & 11.87547 & -2.52 & 0.012 & $-49.48658-10.41976$ \\
\hline
\end{tabular}

Coef. - estimates of coefficients $\beta$; Std. Err. - standard errors of estimates; P - significance level; Conf. Interval confidence interval; Const. - constant.

Source: developed by the authors.

In this model, the significance level for the regression coefficient for the index of GERD share financed by the private non-profit sector is 0.143 . It exceeds the allowable value of 0.05 and indicates the statistical insignificance of the regression coefficient in the obtained model.

Thus, the formed models for estimating the impact of GERD share financed by the private non-profit sector on the annual change in GDP per capita are inadequate. Accordingly, financing GERD from this source is inefficient.

Conclusions. According to the above mentioned, there could be made the conclusions as follows.

1. Models to estimate the influence made by the financial maintenance sources structure of the country's innovative development on the economic growth (growth (change) of GDP per capita) are constructed:

- $\quad$ R\&D financing by government sector:

$\mathrm{GDP}_{G S}=-0.15 \mathrm{GS}+0.55 \mathrm{II}-0.54 \mathrm{IO}+0.33 \mathrm{~L}+0.32 \mathrm{I}-10.03$

- $\quad$ R\&D financing by the business sector:

$\mathrm{GDP}_{\mathrm{BS}}$ it $=-41.96-0.16 \mathrm{GDP}_{\mathrm{BS}} \mathrm{i}, \mathrm{t}-2+0.13 \mathrm{BS} \mathrm{S}_{\mathrm{i}, \mathrm{t}-2}+0.5 \mathrm{ll}_{\mathrm{it}}-0.53 \mathrm{I}_{\mathrm{it}}+0.57 \mathrm{~L}_{\text {it }}-0.13 \mathrm{l}_{\text {it }}$

- $\quad$ R\&D financing by the higher education sector:

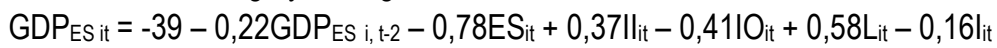

- $\quad$ R\&D financing by foreign sources: 


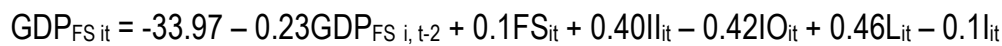

2. The following hypotheses are empirically confirmed:

- $\quad$ with an increase in the share of GERD financed by the government sector (in total GERD) by $1 \%$, the annual increase (change) in GDP per capita will decrease by an average of $0.15 \%$ (excluding time lag) (probability of the hypothesis erroneous acceptance is $1 \%$ );

- $\quad$ with an increase in the share of GERD financed by the business sector (in total GERD) by $1 \%$, the annual increase (change) in GDP per capita will increase by an average of $0.13 \%$ with a time lag of 2 years (probability of the hypothesis erroneous acceptance is $0.6 \%$ );

- $\quad$ with an increase in the share of GERD financed by the higher education sector (in total GERD) by $1 \%$, the annual increase (change) in GDP per capita will decrease by an average of $0.78 \%$ (excluding time lag) (the probability of hypothesis erroneous acceptance is $5.4 \%$ );

- $\quad$ with an increase in the share of GERD financed by foreign sources (in total R\&D) by $1 \%$, the annual increase (change) in gross domestic product per capita will increase by an average of $0.1 \%$ (excluding time lag) (the probability of erroneous acceptance of the hypothesis is $1.5 \%$ ).

- $\quad$ the inefficiency of R\&D financing by the private non-profit sector is empirically confirmed.

3. Taking into account the European countries' experience to stimulate economic growth and development of international reproductive relations in Azerbaijan and Ukraine, the state should reduce the share of direct investment in innovation, focusing on effective legislation. It motivates the business sector and foreign investors to increase investment in research and development. Thus, the hypothesis confirms that business is the best consumer of R\&D results since it has more opportunities to monetize the innovation results faster and implement them in production. The length of chain between the emergence of innovation and use results, which are manifested in GDP growth, is reduced. The state's role has to provide effective mechanisms to stimulate the transfer of innovation to the business environment. When the country is the main investor in science and development, the model is less effective in terms of economic growth dynamics.

Author Contributions: conceptualization, methodology, supervision, formal analysis, software, writing-original draft A. S.; investigation, writing-review and editing, writing-second draft A. R.

Funding: This research received no external funding.

\section{References}

Allison, P. D. (2009). Fixed Effects Regression Models. Newbury Park, CA: Sage. [Google Scholar]

Arellano, M. (1987). Computing robust standard errors for within-groups estimators. Oxford Bulletin of Economics and Statistics, 49, 431-434. [Google Scholar]

Arellano, M., \& Bond, S. (1991). Some tests of specification for panel data: Monte Carlo evidence and an application to employment equations. Review of Economic Studies, 58, 277-297. [Google Scholar] [CrossRef]

Arellano-Bond linear dynamic panel-data estimation. Retrieved from https://www.stata.com/manuals13/xtxtabond.pdf

Balashova, S. A. (2015). Assessment of the impact of the state system of R\&D financing on the business sector (on the example of OECD countries). Applied Econometrics, 38(2),.64-80. [Google Scholar]

Baltagi, B. H. (2013). Econometric Analysis of Panel Data. 5th ed. Chichester, UK: Wiley. [Google Scholar]

Baranovskyi O. I., Khutorna M. E. (2018). Methodology of forming the system of ensuring financial stability of credit institutions. Financial and credit activities: problems of theory and practice, Vol. 4, No 27, P. 4-13. [CrossRef]

Bertaccini, B., Biagi, G. (2018). Public Information and Perception of the Environmental Risk about the Works for the City High Speed Railroad Underpass in Florence, Italy. Journal of Tourism and Services 9(17). [CrossRef]

Broughel, J., \& Thierer, A. D. (2019). Technological innovation and economic growth: A brief report on the evidence. Mercatus Research Paper. [Google Scholar]

Eurostat. (2019). Intramural R\&D expenditure (GERD) by source of funds. Retrieved from https://ec.europa.eu/eurostat/databrowser/view/tsc00031/default/table?lang=en 


\section{A., Rzayev, A., Samoilikova. Innovation Financing Structure as a Factor of Economic Growth: Cross Country Analysis.}

Scholar]

Gourieroux, C., \& Monfort, A. (1995). Statistics and econometric models (Vol. 1). Cambridge University Press. [Google

Grossman, G. M., \& Helpman, E. (1991). Innovation and growth in the global economy. MIT press. [Google Scholar]

Hausman, J. A. (1978). Specification tests in econometrics. Econometrica: Journal of the econometric society, 1251-1271.

[GoogleScholar] [CrossRef]

Ketkar, S., \& Ratha, D. (2009). Innovative Financing for Development. The World Bank, Washington.

Kotenko, N. V., Saltykova, H. V., \& Serdyuk, S. H. (2015). Marketing and management tools for finances and services of uncommon organization. Marketing and management of innovations, 4, 20-33. [Google Scholar]

Kuznyetsova A. Ya., Voznyak H. V., Zherebylo I. V. (2018). Social and economic effects of inter-budgetary relations' decentralization in Ukraine: assessment and challenges. Financial and credit activities: problems of theory and practice, Vol. 4, No 27, P. 446-456. [CrossRef]

Kuznyetsova A. Ya., Zherebylo I. V., Klipkova O. I., Kozmuk N. I. (2019). Creation of the value of national enterprises with the help of the innovation centers in the cluster formations. Financial and credit activities: problems of theory and practice, Vol. 2, No 29, P. 391-402. [CrossRef]

Matijová, M., Onuferová, E., Rigelský, E., Stanko, V. (2019). Impact of Selected Indicators of Tourism Capacity and Performance in the Context of the Unemployment Rate in Slovakia. Journal of Tourism and Services, 10(19): 1-23. [CrossRef]

Mazzucato, M., \& Semieniuk, G. (2017). Public financing of innovation: new questions. Oxford Review of Economic Policy, Volume 33, Issue 1, 24-48. [Google Scholar] [CrossRef]

Nelson, R. (2005). Technology, Institutions, and Economic Growth. Harvard University Press. [Google Scholar]

Pearson, K. (1896). Mathematical contributions to the theory of evolution-III. Regression, heredity, and panmixia. Philosophical Transactions of the Royal Society of London, Series A 187, 253-318. [Google Scholar]

Pessoa, A. (2007). Innovation and Economic Growth: What is the Actual Importance of R\&D? FEP Working Papers, 254. [Google Scholar]

Rosenberg, N. (2006). Innovation and Economic Growth. Innovation and Growth in Tourism. [Google Scholar] [CrossRef]

Samoilikova, A. (2020). Financial Policy of Innovation Development Providing: The Impact Formalization. Financial Markets, Institutions and Risks, 4(2), 5-15. [Google Scholar] [CrossRef]

Schunck, R. (2013). Within and between estimates in random-effects models: Advantages and drawbacks of correlated random effects and hybrid models. Stata Journal, 13, 65-76. [Google Scholar] [CrossRef]

Shapiro, S. S., \& Wilk, M. B. (1965). An analysis of variance test for normality (complete samples). Biometrika, 52(3/4), 591 611.[Google Scholar]

Sokolov-Mladenović, S., Cvetanović, S., \& Mladenović, I. (2016). R\&D expenditure and economic growth: EU28 evidence for the period 2002-2012. Economic research-Ekonomska istraživanja, 29(1), 1005-1020. [GoogleScholar] [CrossRef]

Spearman, C. (1904). The proof and measurement of association between two things. American Journal of Psychology, 15 , 72-101. Google Scholar]

State Statistics Service of Ukraine. (2019). Science, technology and innovation. Retrieved from http://www.ukrstat.gov.ua/

State Statistics Service of Ukraine. (2019). Scientific and innovative activity of Ukraine. Statistical collection - 2018. Retrieved from http://www.ukrstat.gov.ua/druk/publicat/kat u/2018/zb/11/zb seu2017 e.pdf

The Global Innovation Index 2018: Energizing the World with Innovation. (2018). Cornell University, INSEAD, and WIPO: Ithaca, Fontainebleau, and Geneva. 2018. 429 p. Retrieved from https://www.globalinnovationindex.org/userfiles/file/reportpdf/GII2018/Front-and-back-covers.pdf

The Global Innovation Index 2019: Creating Healthy Lives-The Future of Medical Innovation (2019). Cornell University, INSEAD, and WIPO: Ithaca, Fontainebleau, and Geneva., 2019. 451 p. Retrieved from https://www.globalinnovationindex.org/userfiles/file/reportpdf/gii-full-report-2019.pdf

The World Bank Group. (2019). Foreign direct investment, net inflows (\% of GDP). Retrieved from https://data.worldbank.org/indicator/BX.KLT.DINV.WD.GD.ZS

The World Bank Group. (2019). Foreign direct investment, net outflows (\% of GDP). Retrieved from https://data.worldbank.org/indicator/BM.KLT.DINV.WD.GD.ZS

The World Bank Group. (2019). GDP per capita growth (annual \%). Retrieved from https://data.worldbank.org/indicator/NY.GDP.PCAP.KD.ZG

The World Bank Group. (2019). Inflation, GDP deflator (annual \%). Retrieved from https://data.worldbank.org/indicator/NY.GDP.DEFL.KD.ZG?locations=PE

The World Bank Group. (2019). Labor force participation rate, total (\% of total population ages 15-64) (modeled ILO estimate). Retrieved from https://data.worldbank.org/indicator/SL.TLF.ACTI.ZS?locations=PE

The World Bank Group. (2019). Research and development expenditure (\% of GDP). Retrieved from https://data.worldbank.org/indicator/GB.XPD.RSDV.GD.ZS

Vovchak O. D., Rudevska V. I., Pohorila O. V. (2018). Challenges of inflation targeting in Ukraine: establishing the megaregulator. Financial and credit activities: problems of theory and practice, Vol. 1, No 24, P. 305-311. [CrossRef] 


\section{A., Rzayev, A., Samoilikova. Innovation Financing Structure as a Factor of Economic Growth: Cross Country Analysis.}

Анар Pзаєв, Ph.D., доцент, Азербайджанський Державний Економічний Університет, Азербайджан

Анастасія Самойлікова, Сумський державний університет, Україна

Структура фінансування інновацій як фактор економічного зростання: порівняльний аналіз за країнами

У рамках даного дослідження, автори оцінюють вплив джерел фінансування інноваційної діяльності на економічне зростання та розвиток міжнародних відносин. Головною метою $є$ визначення взаємозв'язку між рівнем економічного зростання країни (приріст ВВП на душу населення) та величиною витрат на інноваційну діяльність, які фрінансуються різними секторами економіки (державою, приватним некомерційним сектором, іноземними інвесторами і сектором вищоі освіти). Емпіричне дослідження проведено на основі панельних даних, сформованих для вибірки з 12 країн Європи за 20072017 рр. У ході дослідження застосовано наступну логічну послідовність. На першому етапі оцінено характер розподілу досліджуваних змінних за допомогою тесту Шапіро-Вілка. На основі отриманих результатів обрано метод розрахунку коефріцієнту кореляції: Пірсона - для показників, що підпорядковуються закону нормального розподілу, або Спірмена - для показників, які не підпорядковуються закону нормального розподілу. Авторами проведено кореляційний аналіз сили $і$ характеру зв'язку змінних з динамікою ВВП на душу населення в досліджуваних країнах з метою виявлення тривалост часових лагів, по закінченню яких цей зв'язок є найбільш статистично значущим. На другому етапі з метою виявлення впливу інновацій на динаміку економічного зростання побудовано 3 типи регресійних моделей оцінювання панельних даних: 1) фіксовану (на основі методу найменших квадратів); 2) випадкову (на основі загального методу найменших квадратів; 3) динамічну модель Ареллано-Бонда, що враховує тимчасові лаги (на основі загального методу моментів. На третьому етапі обрано найбільш адекватну специфікацію моделі за допомогою тестів Вальда, Бройша-Пагана та Хаусмана. У роботі проведено тест Саргана на валідність параметрів з метою вибору динамічної моделі АрелланоБонда. Контрольними змінними у всіх трьох типах моделей є чисті притоки і відтоки іноземних інвестицій, кількість економічно активного населення в країні і рівень інфрляції. За отриманими результатами визначено, що зростання частки витрат на науково-дослідні та дослідно-конструкторські роботи (НДДКР) на 1 \%, призводить до зниження річного приросту ВВП на душу населення у середньому на 0,15 \% (без часового лагу) за умови фінансування державним сектором; до збільшення на 0,13 \% з часовим лагом у 2 роки - підприємницьким сектором; до збільшення на 0,1% (без часового лагу) - за рахунок іноземних джерел; до зниження на 0,78 \% (без часового лагу) - сектором вищої освіти. У статті автори приходять до висновку, що з метою забезпечення економічного зростання та розвитку міжнародних відносин в Азербайджані та Україні, необхідно скоротити прямі державні інвестиції в інновації. При иьому уряд має зосередитись на створенні ефективного законодавства, яке мотивуватиме підприємницький сектор та іноземних інвесторів збільшувати інвестиції в НДДКР.

Ключові слова: бізнес сектор, кореляційний аналіз, динамічна модель, економічне зростання, фінансова політика, структура фінансування, іноземні джерела, витрати на НДДКР, державний сектор, формалізація впливу, інновація, регресійна модель, НДДКР.

Manuscript received: 19.03.2020

(C) The author(s) 2020. This article is published with open access at Sumy State University. 